\title{
Deactivation of Pd Catalysts by Water during Low Temperature Methane Oxidation Relevant to Natural Gas Vehicle Converters
}

\author{
Rahman Gholami, Mina Alyani and Kevin J. Smith * \\ Department of Chemical \& Biological Engineering, University of British Columbia, 2360 East Mall, \\ Vancouver, BC V6T 1Z3, Canada; E-Mails: rgshahrestani@chbe.ubc.ca (R.G.); \\ malyani@chbe.ubc.ca (M.A.) \\ * Author to whom correspondence should be addressed; E-Mail: kjs@mail.ubc.ca; \\ Tel.: +1-604-822-3601; Fax: +1-604-822-6003.
}

Academic Editor: Calvin H. Bartholomew

Received: 17 December 2013 / Accepted: 25 March 2015 / Published: 31 March 2015

\begin{abstract}
Effects of $\mathrm{H}_{2} \mathrm{O}$ on the activity and deactivation of $\mathrm{Pd}$ catalysts used for the oxidation of unburned $\mathrm{CH}_{4}$ present in the exhaust gas of natural-gas vehicles (NGVs) are reviewed. $\mathrm{CH}_{4}$ oxidation in a catalytic converter is limited by low exhaust gas temperatures $\left(500-550{ }^{\circ} \mathrm{C}\right)$ and low concentrations of $\mathrm{CH}_{4}(400-1500 \mathrm{ppmv})$ that must be reacted in the presence of large quantities of $\mathrm{H}_{2} \mathrm{O}(10-15 \%)$ and $\mathrm{CO}_{2}(15 \%)$, under transient exhaust gas flows, temperatures, and compositions. Although Pd catalysts have the highest known activity for $\mathrm{CH}_{4}$ oxidation, water-induced sintering and reaction inhibition by $\mathrm{H}_{2} \mathrm{O}$ deactivate these catalysts. Recent studies have shown the reversible inhibition by $\mathrm{H}_{2} \mathrm{O}$ adsorption causes a significant drop in catalyst activity at lower reaction temperatures (below $450{ }^{\circ} \mathrm{C}$ ), but its effect decreases (water adsorption becomes more reversible) with increasing reaction temperature. Thus above $500{ }^{\circ} \mathrm{C} \mathrm{H}_{2} \mathrm{O}$ inhibition is negligible, while $\mathrm{Pd}$ sintering and occlusion by support species become more important. $\mathrm{H}_{2} \mathrm{O}$ inhibition is postulated to occur by either formation of relatively stable $\mathrm{Pd}(\mathrm{OH})_{2}$ and/or partial blocking by $\mathrm{OH}$ groups of the $\mathrm{O}$ exchange between the support and $\mathrm{Pd}$ active sites thereby suppressing catalytic activity. Evidence from FTIR and isotopic labeling favors the latter route. Pd catalyst design, including incorporation of a second noble metal ( $\mathrm{Rh}$ or $\mathrm{Pt}$ ) and supports high $\mathrm{O}$ mobility (e.g., $\mathrm{CeO}_{2}$ ) are known to improve catalyst activity and stability. Kinetic studies of $\mathrm{CH}_{4}$ oxidation at conditions relevant to natural gas vehicles have
\end{abstract}


quantified the thermodynamics and kinetics of competitive $\mathrm{H}_{2} \mathrm{O}$ adsorption and $\mathrm{Pd}(\mathrm{OH})_{2}$ formation, but none have addressed effects of $\mathrm{H}_{2} \mathrm{O}$ on $\mathrm{O}$ mobility.

Keywords: natural gas vehicle; exhaust gas; methane; oxidation; catalyst; deactivation; palladium; water

\section{Introduction}

Natural gas, an abundant energy resource with worldwide proven reserves of over 204.7 trillion $\mathrm{m}^{3}$ [1], is used primarily for electricity generation and heating. The composition of natural gas (NG) is highly variable, but $\mathrm{CH}_{4}$ typically accounts for $80-90 \%$ of the components of $\mathrm{NG}$. $\mathrm{CH}_{4}$ has the highest $\mathrm{H} / \mathrm{C}$ ratio among all hydrocarbon fuels and during combustion, generates the lowest amount of $\mathrm{CO}_{2}$ per unit of energy. The amount of $\mathrm{SO}_{2}$ generated during $\mathrm{NG}$ combustion is also relatively low because the $\mathrm{S}$ content of NG is significantly lower than that of gasoline or diesel fuels. These environmental benefits, together with a relatively low cost of $\mathrm{NG}$, have resulted in an increased interest in its use as a transportation fuel. Currently there are $>16$ million natural gas vehicles (NGVs) in operation around the world, and their numbers are growing at about $20 \%$ annually [2]. However, a significant concern for the wide-spread implementation of $\mathrm{NG}$ as a fuel for combustion engines is that unburned $\mathrm{CH}_{4}$, expelled in the engine exhaust, is a significant greenhouse gas with potency more than $25 \mathrm{xs}$ that of $\mathrm{CO}_{2}$.

The transportation sector is a major contributor to air pollution through the combustion of gasoline and diesel fuels, accounting for $\sim 77 \%$ of $\mathrm{CO}$ emissions, $\sim 47 \%$ of hydrocarbon emissions and $\sim 60 \%$ of $\mathrm{NO}_{x}$ emissions in the USA [3]. The exhaust gas of a conventional gasoline powered spark-ignition internal combustion engine (SI-ICE) consists mostly of $\mathrm{N}_{2}(70-75 \%), \mathrm{CO}_{2}(11-13 \%)$ and water (10$12 \%$ ) with about $1-2 \%$ of pollutants, specifically unburned hydrocarbons, $\mathrm{CO}$ and $\mathrm{NO}_{x}[4,5]$. The pollutants must be removed before the exhaust gas is emitted to the atmosphere so as to meet increasingly stringent worldwide emission standards. The pollutants present in the engine exhaust are dependent on the engine air/fuel (A/F) ratio. For example, if the $\mathrm{A} / \mathrm{F}$ ratio is above the stoichiometric value for complete combustion $(\mathrm{A} / \mathrm{F}=14.6)$, the concentration of reducing agents (hydrocarbons and $\mathrm{CO})$ in the exhaust gas decreases whereas the concentration of oxidizing agents $\left(\mathrm{O}_{2}\right.$ and $\left.\mathrm{NO}_{x}\right)$ increases. Consequently, several different strategies have been developed to control engine emissions, depending on the operating conditions and the target emission levels [5]. Typically, a gasoline engine management system controls the $\mathrm{A} / \mathrm{F}$ ratio or the exhaust gas composition (using an oxygen sensor connected to a secondary air supply) near the stoichiometric value. A single three-way catalyst (TWC) bed, placed in the exhaust gas flow, ensures simultaneous oxidation of the $\mathrm{CO}$ and hydrocarbons and the reduction of the $\mathrm{NO}_{x}$. Alternatively, dual-bed systems combine a $\mathrm{NO}_{x}$ reduction catalyst bed with a separate oxidation catalyst and secondary air to remove the $\mathrm{CO}$ and hydrocarbons. Under lean-burn conditions a gasoline engine may operate with sufficiently high $\mathrm{A} / \mathrm{F}$ ratios so as to obtain a significant reduction in $\mathrm{CO}$ and $\mathrm{NO}_{x}$ emissions and improved fuel efficiency. The function of the catalyst in this case is limited to the oxidation of mainly hydrocarbons, while the $\mathrm{NO}_{x}$ emissions are captured using a $\mathrm{NO}_{x}$ trap followed by desorption and reduction in a TWC during an occasional near stoichiometric 
excursion of the engine. Although lean-burn engines improve fuel efficiency, the exhaust gas temperature is significantly lower than from conventional gasoline powered engines, and consequently, catalysts with high oxidation activity at relatively low temperatures are needed for this application [5].

Modern TWC converters used in gasoline ICEs contain Pt, $\mathrm{Rh}$ and $\mathrm{Pd}$, dispersed on a washcoat applied to a cordierite ceramic monolith or metal monolith [3,5]. The monolith usually has a honeycomb structure with $1 \mathrm{~mm}$ square channels to accommodate the high gas throughputs from the exhaust with minimal pressure drop. The washcoat, a mix of several metal oxides $\left(\mathrm{Al}_{2} \mathrm{O}_{3}, \mathrm{CeO}_{2}, \mathrm{ZrO}_{2}\right)$, is applied to increase the metal support surface area $\left(\mathrm{Al}_{2} \mathrm{O}_{3}\right)$, to improve thermal stability $\left(\mathrm{ZrO}_{2}\right)$ and to provide enhanced oxygen storage capacity $\left(\mathrm{CeO}_{2}\right)$ that widens the operating range for optimal oxidation and reduction by the catalyst. The metal composition of the converter varies with application but typically contains 5-20:1 of Pt:Rh with a total metal loading of $0.9-2.2 \mathrm{~g} \mathrm{~L}^{-1}$. Pd may be used to replace all or part of the Pt for cost savings [5].

Exhaust gas emissions from NGVs are difficult to control because low concentrations of $\mathrm{CH}_{4}$ (400-1500 ppmv) must be oxidized in the presence of high concentrations of $\mathrm{H}_{2} \mathrm{O}(10-15 \mathrm{vol} . \%)$ and $\mathrm{CO}_{2}\left(15\right.$ vol.\%) at relatively low exhaust gas temperatures $\left(450-550{ }^{\circ} \mathrm{C}\right)$. The greater strength of the C-H bond in $\mathrm{CH}_{4}(450 \mathrm{~kJ} / \mathrm{mol})$ relative to other hydrocarbons [6] implies that catalysts with high $\mathrm{CH}_{4}$ oxidation activity must be used. NGVs operate near the stoichiometric point or under lean-burn conditions [7,8]. Stoichiometric NGV engines are primarily used in light-duty passenger cars, whereas lean-burn engines are more common in heavy-duty vehicles such as buses. Over the past $\sim 20$ years, conventional converter technologies have been adapted for NGVs using Pd catalysts (which have the highest activity for $\mathrm{CH}_{4}$ oxidation $[7,9,10]$ ) to adequately reduce (by $50-60 \%$ ) the $\mathrm{CH}_{4}$ content in $\mathrm{NGV}$ exhausts at $<500{ }^{\circ} \mathrm{C}$ in the presence of high $\mathrm{H}_{2} \mathrm{O}$ concentrations. Commercial catalysts for SI-NG engines also typically incorporate a $\mathrm{CeO}_{2} / \mathrm{ZrO}_{2}$ solid solution for high $\mathrm{O}_{2}$ adsorption capacity, which serves to buffer $\mathrm{O}_{2}$ concentration during the rapid switching between slightly oxidizing and reducing conditions close to a stoichiometric mixture (e.g., [7,11]).

Several papers and reviews have assessed the activity and deactivation of $\mathrm{Pd}$ catalysts for $\mathrm{CH}_{4}$ oxidation, supported on $\mathrm{Al}_{2} \mathrm{O}_{3}, \mathrm{SiO}_{2}, \mathrm{ZrO}_{2}, \mathrm{CeO}_{2}$, and zeolites; promoted with noble metals, e.g., $\mathrm{Pt}$ and $\mathrm{Rh}$, and with transition metal oxides, e.g., oxides of $\mathrm{Co}, \mathrm{Ni}$, and $\mathrm{Sn}$ [6,7,10-20]. Studies have largely focused on $\mathrm{CH}_{4}$ oxidation on supported $\mathrm{Pd}$ catalysts containing 0.5 to $5 \% \mathrm{Pd}$ (typical $\mathrm{Pd}$ loadings in commercial SI-NG monolithic coated catalysts are about 3-7 g. $\mathrm{L}^{-1}$, equivalent to about 1.5-4 wt.\% loading in a monolith washcoat) at temperatures ranging from 450 to $600{ }^{\circ} \mathrm{C}$ and at $\mathrm{CH}_{4}$ concentrations of 0.04 to 1 vol.\% (0.04 to 0.15 vol.\% for commercially representative tests). High activity for $\mathrm{CH}_{4}$ oxidation appears to be favored by Pd loadings of 3-5 $\mathrm{g} \mathrm{L}^{-1}$ and dispersions lower than about $0.12-0.15$ [7]. Pd-O sites associated with $\mathrm{Pd} / \mathrm{CeO}_{2}$ surfaces appear to have the highest activity for $\mathrm{CH}_{4}$ oxidation [21,22].

Mechanisms and kinetics of $\mathrm{CH}_{4}$ oxidation over $\mathrm{Pd} / \mathrm{PdO}$ catalysts have elicited continued debate in the literature $[6,13,14,23]$, for which data interpretation is complicated by the transitions that $\mathrm{Pd}$ catalysts undergo during thermal pre-treatment and reaction [24]. Furthermore, the high concentration of $\mathrm{H}_{2} \mathrm{O}$ in the $\mathrm{NGV}$ exhaust and the typically transient reaction conditions that result from cycling 
between oxidizing and reducing conditions in the NG engine [6,11] are known to significantly impact catalyst activity and stability.

The present review is focused on the inhibition and deactivation effects of $\mathrm{H}_{2} \mathrm{O}$, especially at the relatively low temperatures representative of $\mathrm{CH}_{4}$ oxidation over $\mathrm{Pd}$ catalysts in a $\mathrm{NG}$ engine. Although previous reviews have addressed the issue of $\mathrm{Pd}$ catalyst stability in the presence or absence of $\mathrm{H}_{2} \mathrm{O}[4,12,20,25]$, and several catalyst deactivation mechanisms are possible at the exhaust gas conditions [26], several unresolved issues remain. More recent studies of the past decade have provided new insights into the effects of $\mathrm{H}_{2} \mathrm{O}$, especially at lower temperatures, and these are the focus of the present review. Note, however, that in many cases, fresh catalysts in powder form have been evaluated using ideal fixed-bed micro-reactors and simulated exhaust gas under steady state operating conditions. Tests of monolith catalysts with promoters suitably aged and operated with A/F frequency and amplitude modulation that occur in a vehicle are few [7,11]. Nonetheless, interpretation of data from ideal catalyst studies allows direct links to be drawn between fundamental catalyst properties and catalyst performance for $\mathrm{CH}_{4}$ oxidation, whereas in real systems this may be more difficult to achieve.

\section{Effects of $\mathrm{H}_{2} \mathrm{O}$ on $\mathrm{CH}_{4}$ Oxidation over Pd Catalysts}

Water is a major component of the engine exhaust and is also a product of the combustion that occurs in the catalytic converter. In TWCs, $\mathrm{H}_{2} \mathrm{O}$ acts as an oxidizing agent for $\mathrm{CO}$ conversion by the water-gas-shift reaction and for steam reforming of hydrocarbons [4]. $\mathrm{H}_{2} \mathrm{O}$ also significantly affects the thermal stability of the metals (Pt, Rh and Pd) present in the TWC as well as the support, mostly through sintering mechanisms $[4,27,28]$ and by changes in the Pd oxidation state during hydrothermal aging [29]. Water may also act as a reaction inhibitor by adsorption onto the catalyst.

Bounechada et al. [11] reported on the activity of a $\mathrm{Pd}-\mathrm{Rh}(\mathrm{Pd} / \mathrm{Rh}=39 / 1) \mathrm{TWC}$ converter supported on stabilized $\mathrm{Al}_{2} \mathrm{O}_{3}$, promoted with $\mathrm{Ce}-\mathrm{Zr}(\mathrm{Zr} / \mathrm{Ce}=3.5)$ and wash coated on a ceramic honeycomb monolith, tested under fuel-lean $(\lambda>1)$, stoichiometric $(\lambda=1.00)$, and fuel-rich $(\lambda<1)$ conditions (gas composition: 0.15 vol. $\% \mathrm{CH}_{4}, 0.6 \% \mathrm{CO}, 0.1 \% \mathrm{H}_{2}, 10 \% \mathrm{H}_{2} \mathrm{O}, 10.7 \% \mathrm{CO}_{2}, 0.13 \% \mathrm{NO}$, $0-1.14 \% \mathrm{O}_{2} ; \lambda$ was varied by changing feed $\mathrm{O}_{2}$ concentration; GHSV $=50,000 \mathrm{~h}^{-1}$ ). At stationary conditions (constant $\lambda$; steady-state experiment), the $\mathrm{CH}_{4}$ conversion was observed to continuously decrease under both stoichiometric ( 52 to $43 \%$ after $0.5 \mathrm{~h}$ reaction) and fuel-lean (from 62 to $59 \%$ after $0.5 \mathrm{~h}$ reaction) conditions, even though injecting a fuel-rich pulse during fuel-lean stationary operation increased the $\mathrm{CH}_{4}$ conversion to its initial value at the onset of reaction. The authors attributed the deactivation under fuel-lean conditions to the inhibition effect of $\mathrm{H}_{2} \mathrm{O}$ on the $\mathrm{CH}_{4}$ oxidation reaction, whereas under stoichiometric conditions, partial reduction of PdO due to the lack of oxygen, may lead to a loss in $\mathrm{PdO}$ active sites for $\mathrm{CH}_{4}$ oxidation. The authors also claimed that the presence of high oxygen capacity metals ( $\mathrm{Ce}$ and $\mathrm{Zr}$ ) in the catalyst made the reduction of $\mathrm{PdO}$ improbable under stoichiometric conditions. Under fuel-rich conditions, $\mathrm{H}_{2} \mathrm{O}$ acts as an oxidant through water-gas shift and steam reforming reactions. 


\subsection{Water Concentration and Reaction Temperature Effects on $\mathrm{CH}_{4}$ Oxidation Activity of Pd Catalysts}

With the growing interest in NGVs, recent studies have focused on effects of $\mathrm{H}_{2} \mathrm{O}$ on $\mathrm{Pd}$ catalysts during $\mathrm{CH}_{4}$ combustion [16,18,30-38]. Deactivation or inhibition effects of $\mathrm{H}_{2} \mathrm{O}$ are dependent upon several factors including catalyst formulation, reaction temperature, catalyst time-on-stream history, and $\mathrm{H}_{2} \mathrm{O}$ concentration. Table 1 summarizes selected data that show effects of $\mathrm{H}_{2} \mathrm{O}$ added to the feed gas during $\mathrm{CH}_{4}$ light-off experiments over Pd catalysts. The light-off temperature (here reported as the temperature corresponding to $30 \% \mathrm{CH}_{4}$ conversion during temperature programmed reaction, $T_{30}$ ) increases as the $\mathrm{H}_{2} \mathrm{O}$ concentration increases, showing a clear inhibition effect that increases in magnitude with increasing $\mathrm{H}_{2} \mathrm{O}$ concentration.

In several cases the effects of $\mathrm{H}_{2} \mathrm{O}$ have been examined by measuring the $\mathrm{CH}_{4}$ conversion at steady-state, with and without $\mathrm{H}_{2} \mathrm{O}$ added to the feed gas. A typical set of data, reported by Persson et al. [35], is shown in Figure 1 using several $\mathrm{Pd} / \mathrm{Al}_{2} \mathrm{O}_{3}$ catalysts reacted at $500{ }^{\circ} \mathrm{C}$. These data also show that added $\mathrm{H}_{2} \mathrm{O}$ significantly suppresses $\mathrm{CH}_{4}$ conversion, but the effect is at least partially reversible. Similar effects of $\mathrm{H}_{2} \mathrm{O}$ addition have been reported in the literature, as summarized in Table 2. These reports confirm that $\mathrm{H}_{2} \mathrm{O}$ acts as an inhibitor of $\mathrm{CH}_{4}$ oxidation over Pd catalysts and that upon removal of the $\mathrm{H}_{2} \mathrm{O}$ from the $\mathrm{CH}_{4} / \mathrm{O}_{2}$ reactant, the inhibition is partially reversible $[31,33]$.

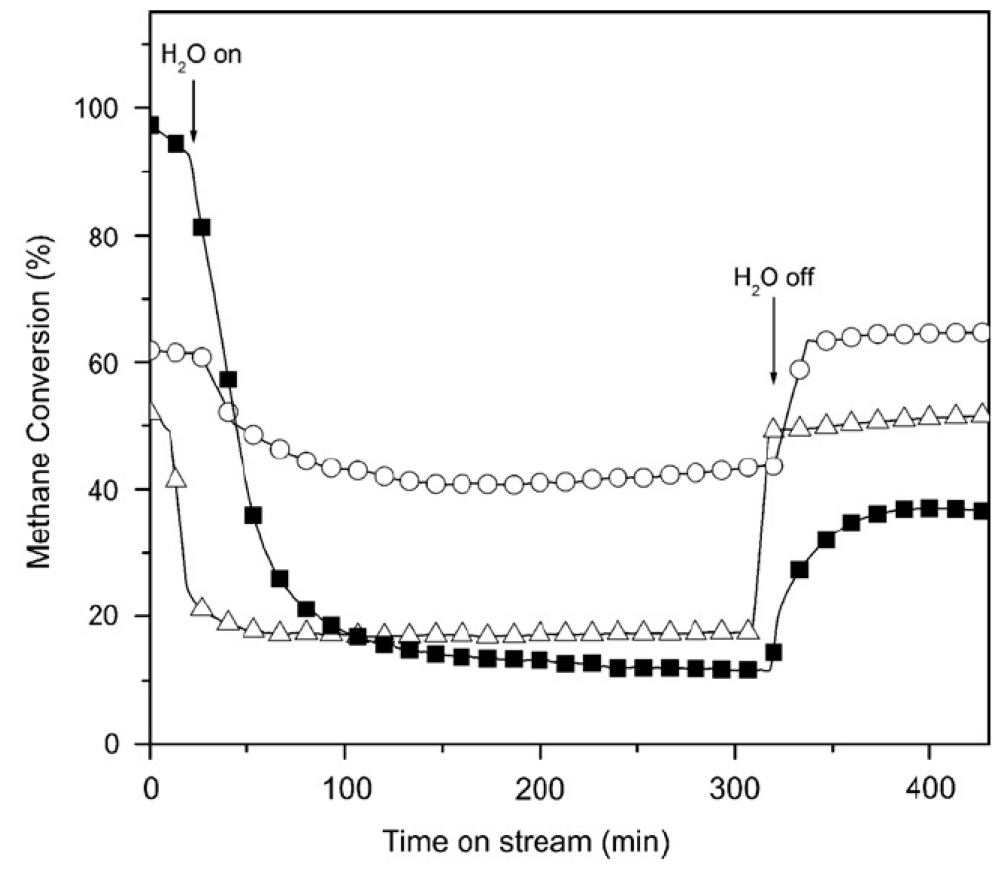

Figure 1. Effect of water vapor on the activity for $\mathrm{CH}_{4}$ combustion over $\mathrm{Pd} / \mathrm{Al}_{2} \mathrm{O}_{3}(\mathbf{\square}) ; 2: 1$ $\mathrm{PdPt} / \mathrm{Al}_{2} \mathrm{O}_{3}(\Delta)$; and $1: 1 \mathrm{PdPt} / \mathrm{Al}_{2} \mathrm{O}_{3}$ (o) at $500{ }^{\circ} \mathrm{C} ; 5$ vol. $\%$ of steam was added to the $1.5 \%$ $\mathrm{CH}_{4} /$ air feed gas, GHSV $=100,000 \mathrm{~h}^{-1}$, for 5 h. [35] Copyright $(2007$ Elsevier. 
Table 1. Effect of $\mathrm{H}_{2} \mathrm{O}$ addition on $T_{30}$ (temperature at $30 \% \mathrm{CH}_{4}$ conversion) during temperature-programmed $\mathrm{CH}_{4}$ oxidation over Pd catalysts.

\begin{tabular}{|c|c|c|c|c|c|}
\hline & \multicolumn{3}{|c|}{ Reference [16] } & \multicolumn{2}{|c|}{ Reference [39] } \\
\hline & $1.1 \% \mathrm{Pd} / \mathrm{Al}_{2} \mathrm{O}_{3}$ & $1.1 \% \mathrm{Pd} / \mathrm{SnO}_{2}$ & $1.1 \% \mathrm{Pd} / \mathrm{Al}_{2} \mathrm{O}_{3}-36 \mathrm{NiO}$ & $0.9 \% \mathrm{Pd} / \mathrm{ZrO}_{2}{ }^{\mathrm{a}}$ & $0.9 \% \mathrm{Pd} / \mathrm{ZrO}_{2}{ }^{\mathrm{b}}$ \\
\hline GHSV, $\mathrm{h}^{-1}$ & \multicolumn{3}{|c|}{48,000} & \multicolumn{2}{|c|}{50,000} \\
\hline Dry feed gas composition, vol.\% & \multicolumn{3}{|c|}{$\begin{array}{c}1 \% \mathrm{CH}_{4} / 20 \% \mathrm{O}_{2} \text { in } \mathrm{N}_{2} \\
T_{30},{ }^{\circ} \mathrm{C}\end{array}$} & \multicolumn{2}{|c|}{$\begin{array}{c}0.4 \% \mathrm{CH}_{4} / 0.05 \% \mathrm{CO} / 5 \% \mathrm{CO}_{2} / 10 \% \mathrm{O}_{2} \text { in } \mathrm{N}_{2} \\
T_{30},{ }^{\circ} \mathrm{C}\end{array}$} \\
\hline \multicolumn{6}{|l|}{ Added $\mathrm{H}_{2} \mathrm{O}$, vol. $\%$} \\
\hline 0 & 345 & 290 & 372 & 360 & 300 \\
\hline 1 & 400 & 315 & 372 & - & - \\
\hline 5 & 430 & 335 & 420 & - & - \\
\hline 10 & 460 & 360 & 425 & 410 & 350 \\
\hline 20 & 510 & 365 & 445 & - & - \\
\hline
\end{tabular}

${ }^{\mathrm{a}}$ Calcined at $873 \mathrm{~K}$ for $6 \mathrm{~h} ;{ }^{\mathrm{b}}$ Calcined at $1273 \mathrm{~K}$ for $6 \mathrm{~h}$.

Table 2. $\mathrm{H}_{2} \mathrm{O}$ inhibition over $\mathrm{Pd}$ catalysts during $\mathrm{CH}_{4}$ oxidation.

\begin{tabular}{|c|c|c|c|c|c|c|c|c|c|c|}
\hline \multirow{3}{*}{ Catalyst } & \multirow{2}{*}{\multicolumn{3}{|c|}{ Reaction conditions }} & \multirow{3}{*}{$\begin{array}{l}\text { Conc. } \\
\text { vol } \%\end{array}$} & \multirow{3}{*}{$\begin{array}{l}\text { Period }^{\mathrm{a}} \\
\min \end{array}$} & \multicolumn{3}{|c|}{ Water addition } & \multirow{3}{*}{ Comments } & \multirow{3}{*}{ Refs. } \\
\hline & & & & & & $\mathrm{CH}_{4}$ & onversion & $\%$ & & \\
\hline & $\begin{array}{c}\text { Temp } \\
{ }^{\circ} \mathrm{C}\end{array}$ & $\begin{array}{c}\text { GHSV } \\
\mathbf{h}^{-1}\end{array}$ & $\begin{array}{c}\text { Feed Gas } \\
\text { mol \% }\end{array}$ & & & $\begin{array}{l}\text { Before } \\
\qquad \mathrm{H}_{2} \mathrm{O} \\
\text { addition }\end{array}$ & $\begin{array}{l}\text { During } \\
\mathrm{H}_{2} \mathrm{O} \\
\text { addition }\end{array}$ & $\begin{array}{l}\text { After } \\
\mathrm{H}_{2} \mathrm{O} \\
\text { addition }\end{array}$ & & \\
\hline 0.1 wt. $\% \mathrm{Pd} / \mathrm{H}$-beta & 400 & 120,000 & $\begin{array}{c}0.2 \% \mathrm{CH}_{4} / 10 \% \mathrm{O}_{2} \\
\text { in } \mathrm{N}_{2}\end{array}$ & 10 & 100 & 75 & 15 & 58 & $\begin{array}{l}\text { Conversion after } 400 \mathrm{~min} \\
\text { TOS with periodic water } \\
\text { addition }\end{array}$ & {$[38]$} \\
\hline
\end{tabular}


Table 2. Cont.

\begin{tabular}{|c|c|c|c|c|c|c|c|c|c|c|}
\hline \multirow[b]{2}{*}{ Catalyst } & \multicolumn{3}{|c|}{ Reaction conditions } & \multirow{2}{*}{$\begin{array}{l}\text { Conc. } \\
\text { vol } \%\end{array}$} & \multirow[b]{2}{*}{ Period $^{\mathrm{a}}$} & \multicolumn{3}{|c|}{$\begin{array}{c}\text { Water addition } \\
\mathrm{CH}_{4} \text { Conversion, \% }\end{array}$} & \multirow[b]{2}{*}{ Comments } & \multirow[b]{2}{*}{ Refs. } \\
\hline & $\begin{array}{c}\text { Temp } \\
{ }^{\circ} \mathrm{C}\end{array}$ & $\begin{array}{c}\text { GHSV } \\
\mathbf{h}^{-1}\end{array}$ & $\begin{array}{l}\text { Feed Gas } \\
\text { mol \% }\end{array}$ & & & $\begin{array}{c}\text { Before } \\
\mathrm{H}_{2} \mathrm{O} \\
\text { addition } \\
\end{array}$ & $\begin{array}{c}\text { During } \\
\mathrm{H}_{2} \mathrm{O} \\
\text { addition } \\
\end{array}$ & $\begin{array}{c}\text { After } \\
\mathrm{H}_{2} \mathrm{O} \\
\text { addition } \\
\end{array}$ & & \\
\hline $\begin{array}{c}1.3 \text { wt. } \% \text { Pd/HTNU- } \\
10^{c}\end{array}$ & 400 & 120,000 & $\begin{array}{c}1 \% \mathrm{CH}_{4} / 4 \% \mathrm{O}_{2} \text { in } \\
\mathrm{N}_{2}\end{array}$ & 5 & 900 & 43 & 8 & 40 & $\begin{array}{c}\text { Conversion after } 35 \mathrm{~h} \\
\text { TOS with periodic } \\
\text { water addition }\end{array}$ & {$[33]$} \\
\hline 5 wt. $\% \mathrm{Pd} / \mathrm{Al}_{2} \mathrm{O}_{3}$ & 500 & 100,000 & $1.5 \% \mathrm{CH}_{4}$ in air & 5 & 300 & 95 & 13 & 30 & Initial activity & {$[35]$} \\
\hline 2 wt. $\% \mathrm{Pd} / \mathrm{Al}_{2} \mathrm{O}_{3}$ & 550 & 160,000 & $0.4 \% \mathrm{CH}_{4}$ in air & 10 & 60 & 95 & 79 & 92 & $\begin{array}{l}\text { Conversion after } 400 \\
\text { min TOS with periodic } \\
\text { water addition }\end{array}$ & {$[32]$} \\
\hline 1 wt. $\% \mathrm{Pd} / \mathrm{Al}_{2} \mathrm{O}_{3}$ & 600 & 160,000 & $0.4 \% \mathrm{CH}_{4}$ in air & 8 & 60 & 95 & 90 & 93 & $\begin{array}{c}\text { Conversion after } 300 \\
\text { min TOS with periodic } \\
\text { water addition } \\
\end{array}$ & {$[36]$} \\
\hline
\end{tabular}

${ }^{a}$ Period: Time length of water addition period. ${ }^{\mathrm{b}} \mathrm{TOS}$ : Time-on-stream. ${ }^{\mathrm{c}} \mathrm{HTNU}-10$ is the $\mathrm{H}$-form of a medium pore zeolite with $\mathrm{Si} / \mathrm{Al}=7.1$. 
Reaction temperature is another key variable affecting the role of $\mathrm{H}_{2} \mathrm{O}$ addition. Although the data of Table 2 cannot be compared directly because of the different operating conditions, they do show that at $600{ }^{\circ} \mathrm{C}$, the decrease in $\mathrm{CH}_{4}$ conversion with $\mathrm{H}_{2} \mathrm{O}$ addition is much less significant than at lower temperatures $\left(400{ }^{\circ} \mathrm{C}\right)$. Several authors have proposed that the deactivation is related to the reaction of $\mathrm{H}_{2} \mathrm{O}$ with active $\mathrm{PdO}$ sites $[16,18,31,40,41], \mathrm{PdO}+\mathrm{H}_{2} \mathrm{O} \rightarrow \mathrm{Pd}(\mathrm{OH})_{2}$, resulting in the formation of inactive $\mathrm{Pd}(\mathrm{OH})_{2}$, as first proposed by Cullis et al. [40]. Burch et al. [31] also reported a strong inhibitory effect of water on Pd catalysts up to $450{ }^{\circ} \mathrm{C}$. However, at higher temperatures the negative influence of water on the activity was very small, suggesting that above $450{ }^{\circ} \mathrm{C}$ the reverse reaction $\left(\mathrm{Pd}(\mathrm{OH})_{2} \rightarrow \mathrm{PdO}+\mathrm{H}_{2} \mathrm{O}\right)$ occurs. Eriksson et al. [41] observed a significant decrease in $\mathrm{CH}_{4}$ conversion over a much wider range of temperatures $\left(200-800{ }^{\circ} \mathrm{C}\right)$ after adding $18 \% \mathrm{H}_{2} \mathrm{O}$ to a $\mathrm{CH}_{4} / \mathrm{O}_{2}$ feed over a $\mathrm{Pd} / \mathrm{ZrO}_{2}$ catalyst, which was likely due to the relatively high $\mathrm{H}_{2} \mathrm{O}$ concentration used in this study. Different results were reported by Kikuchi et al. [16] when adding 1 vol.\% $\mathrm{H}_{2} \mathrm{O}$ during $\mathrm{CH}_{4}$ oxidation over a $\mathrm{Pd} / \mathrm{Al}_{2} \mathrm{O}_{3}$ catalyst, i.e., a decrease in activity was observed up to about $450{ }^{\circ} \mathrm{C}$ and no $\mathrm{H}_{2} \mathrm{O}$ inhibition was observed at higher temperatures. However, during addition of $20 \mathrm{vol} \% \mathrm{H}_{2} \mathrm{O}$, the inhibiting effect could be observed up to $600^{\circ} \mathrm{C}$, in qualitative agreement with Eriksson et al. [41].

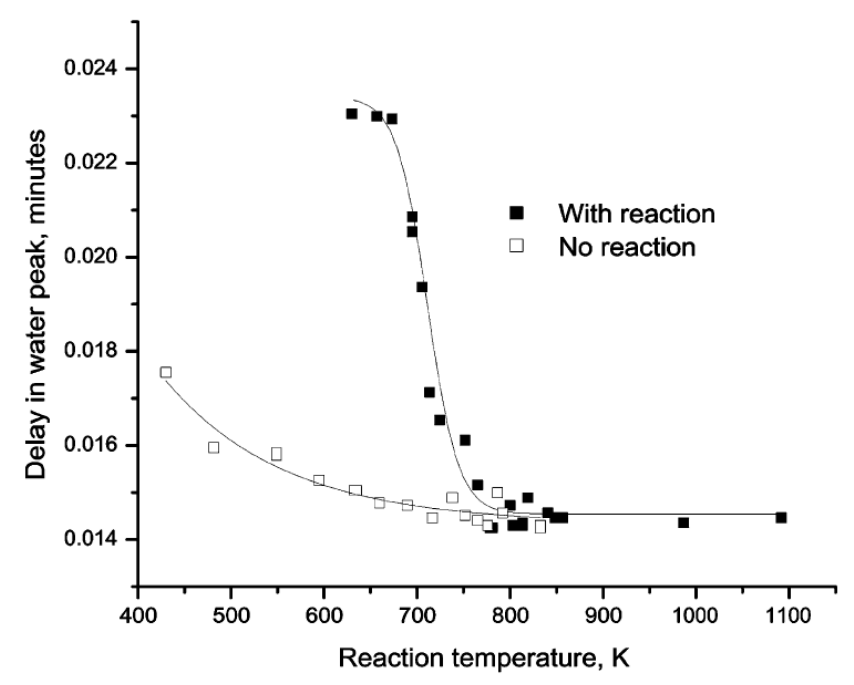

Figure 2. Delay in the $\mathrm{H}_{2} \mathrm{O}$ peak with respect to other products obtained by passing pulses of $\mathrm{CH}_{4} / \mathrm{O}_{2} / \mathrm{He}$ (closed square) and 1 vol.\% $\mathrm{O}_{2} / 3.45$ vol.\% $\mathrm{H}_{2} \mathrm{O} / \mathrm{He}$ (open square) over $\mathrm{Pd} / \mathrm{ZrO}_{2}$ at different temperatures. Reproduced with permission from [42]. Copyright (C) 2001 Elsevier.

Further insight into the $\mathrm{H}_{2} \mathrm{O}$ adsorption/desorption phenomena on $\mathrm{Pd} / \mathrm{ZrO}_{2}$ catalysts has been obtained using pulsed-flow experiments [42,43]. Accordingly, pulses of $\mathrm{CH}_{4} / \mathrm{O}_{2} / \mathrm{He}(1: 4: 95$ vol \%) were passed over a $\mathrm{Pd} / \mathrm{ZrO}_{2}$ catalyst at various temperatures and the products monitored by mass spectrometer. The time at which the peak maximum for $\mathrm{H}_{2} \mathrm{O}$ appeared in each spectrum, compared to other products, was reported as the delay in the $\mathrm{H}_{2} \mathrm{O}$ peak. The data (Figure 2) show that the $\mathrm{H}_{2} \mathrm{O}$ generated during $\mathrm{CH}_{4}$ oxidation lags other products, suggesting a slow $\mathrm{H}_{2} \mathrm{O}$ adsorption/desorption equilibrium which might include spillover to the support. As the temperature increases above $450{ }^{\circ} \mathrm{C}$ $(723 \mathrm{~K})$, the desorption rate of $\mathrm{H}_{2} \mathrm{O}$ increases and the delay in the $\mathrm{H}_{2} \mathrm{O}$ peak compared to the other products is insignificant. This behavior is in agreement with observations from other studies [30,31,44] 
that the desorption rate of $\mathrm{H}_{2} \mathrm{O}$ produced during $\mathrm{CH}_{4}$ oxidation is slow and on the order of seconds below $450{ }^{\circ} \mathrm{C}$, even though $\mathrm{CO}_{2}$, the other product of reaction, desorbs very quickly. Increasing temperature above $450{ }^{\circ} \mathrm{C}$ removes the desorption time gap between $\mathrm{CO}_{2}$ and $\mathrm{H}_{2} \mathrm{O}$, and thus, no inhibition by $\mathrm{H}_{2} \mathrm{O}$ occurs. Ciuparu et al. [42] also pulsed gas containing 3.45 vol. $\% \mathrm{H}_{2} \mathrm{O} / \mathrm{O}_{2} / \mathrm{He}_{\text {but no }}$ $\mathrm{CH}_{4}$ (and hence no reaction) through the same catalyst bed (Figure 2), showing that the $\mathrm{H}_{2} \mathrm{O}$ generated from $\mathrm{CH}_{4}$ oxidation lags the $\mathrm{H}_{2} \mathrm{O}$ added to the feed. These data demonstrate that the adsorption/desorption of $\mathrm{H}_{2} \mathrm{O}$ from the $\mathrm{Pd}$ catalyst surface is temperature dependent and reaches equilibrium at temperatures above $\sim 450{ }^{\circ} \mathrm{C}(723 \mathrm{~K})$, even for $\mathrm{H}_{2} \mathrm{O}$ added in the gas phase.

Figure 3 compares temperature-programmed-reaction (TPR) profiles for $\mathrm{CH}_{4}$ oxidation obtained over a $\mathrm{Pd} / \mathrm{ZrO}_{2}$ catalyst, from both pulsed and continuous flow experiments with or without $\mathrm{H}_{2} \mathrm{O}$ added $[42,43]$. The pulsed flow TPR profile was obtained by injecting pulses of the reaction mixture (1/4/95: $\mathrm{CH}_{4} / \mathrm{O}_{2} / \mathrm{He}$ for the "dry" feed and 1/4/95: $\mathrm{CH}_{4} / \mathrm{O}_{2} / \mathrm{He}$ saturated with $\sim 2 \% \mathrm{H}_{2} \mathrm{O}$ for the "wet" feed) into a He stream every $3 \mathrm{~min}$ while ramping the temperature at $0.5 \mathrm{~K} \mathrm{~min}{ }^{-1}$. Between consecutive pulses the catalyst was purged in flowing He. The pulsed flow data of Figure 3 show that at temperatures above $450{ }^{\circ} \mathrm{C}(723 \mathrm{~K})$, there is no $\mathrm{H}_{2} \mathrm{O}$ inhibition, since the conversions of "dry" and "wet" reaction mixtures are essentially the same. At $<450{ }^{\circ} \mathrm{C}$, inhibition is observed due to a low $\mathrm{H}_{2} \mathrm{O}$ desorption rate. When $\mathrm{H}_{2} \mathrm{O}$ is added to the gas phase, the $\mathrm{H}_{2} \mathrm{O}$ adsorption rate is enhanced and the rate of desorption is further decreased. With continuous flow of reactants and a higher $\mathrm{H}_{2} \mathrm{O}$ concentration, $\mathrm{H}_{2} \mathrm{O}$ inhibition occurs at high temperatures due to re-adsorption. The addition of $\mathrm{H}_{2} \mathrm{O}$ to the feed directs the equilibrium towards more $\mathrm{H}_{2} \mathrm{O}$ adsorption on the surface and hence a greater decrease in catalyst activity during $\mathrm{CH}_{4}$ oxidation.

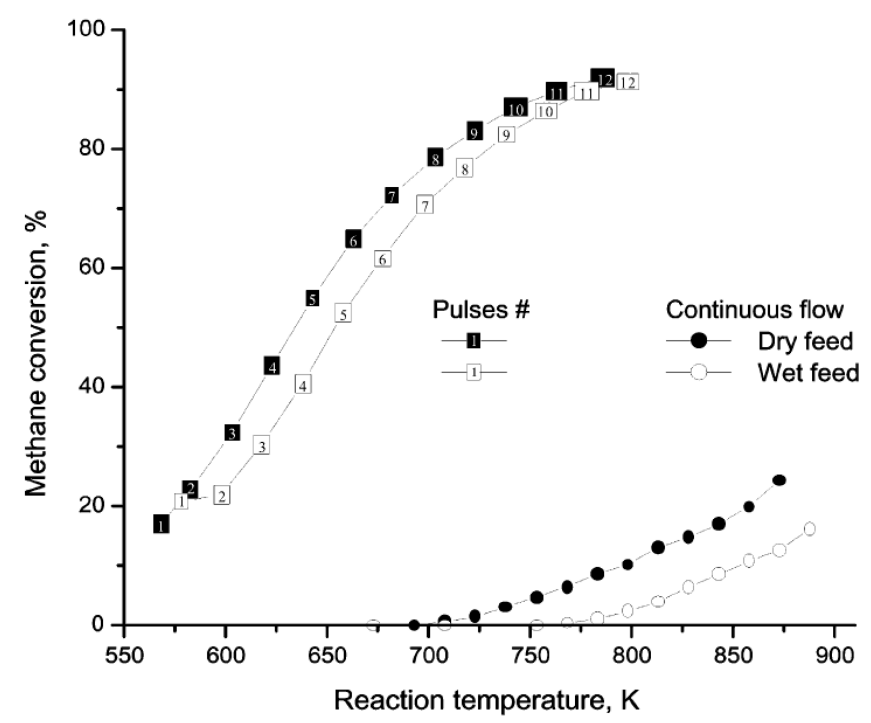

Figure 3. Temperature-programmed reactions during pulsed or continuous flow of reactants over $\mathrm{Pd} / \mathrm{ZrO}_{2}$ with or without $\mathrm{H}_{2} \mathrm{O}$ in the feed. Reproduced with permission from [42]. Copyright (C) 2001 Elsevier.

The above observations are consistent with the following hypotheses: (1) product inhibition of $\mathrm{CH}_{4}$ oxidation by $\mathrm{H}_{2} \mathrm{O}$ on $\mathrm{PdO}$ catalysts occurs at temperatures below $450{ }^{\circ} \mathrm{C}$; (2) product inhibition by $\mathrm{H}_{2} \mathrm{O}$ is enhanced by its slow rate of desorption from the $\mathrm{PdO}$ catalyst relative to a higher rate of $\mathrm{CH}_{4}$ 
oxidation; (3) $\mathrm{PdO}$ and $\mathrm{H}_{2} \mathrm{O}$ may interact via the reversible reaction: $\mathrm{PdO}+\mathrm{H}_{2} \mathrm{O} \leftrightarrow \mathrm{Pd}(\mathrm{OH})_{2}$ yielding inactive $\mathrm{Pd}(\mathrm{OH})_{2}$ and thus reversibly deactivating $\mathrm{PdO}$ as first proposed by Cullis et al. [40]; and (4) the extent of the $\mathrm{CH}_{4}$ oxidation reaction increases with increasing temperature but is reduced with increasing $\mathrm{H}_{2} \mathrm{O}$ concentration in the gas phase.

\subsection{Catalyst Sintering by $\mathrm{H}_{2} \mathrm{O}$}

The possibility that addition of $\mathrm{H}_{2} \mathrm{O}$ may degrade $\mathrm{Pd}$ catalysts through a sintering mechanism [26] has also been investigated. According to Hansen et al. [45], the sintering rate of metal nanoparticles depends on their size. For nanoparticles $<3 \mathrm{~nm}$ in diameter, Ostwald ripening is the most likely sintering mechanism. For larger particles $(3-10 \mathrm{~nm})$, both Ostwald ripening and particle migration and coalescence may occur, but the sintering rate is much slower than for the smaller particles [45]. The particle sintering rate has also been shown to correlate with the vapor pressure of the surface species [4]. $\mathrm{Pd}$ is unique among the PGMs in that the oxide $(\mathrm{PdO})$ has a much lower vapor pressure than the metal (Pd), and consequently, one would expect a very low sintering rate of PdO by Ostwald ripening [4]. The rate of sintering is also dependent on the support. Lamber et al. [46] suggested that on $\mathrm{SiO}_{2}$ in the presence of $\mathrm{H}_{2} \mathrm{O}$, the formation of silanol ( $\left.\mathrm{Si}-\mathrm{OH}\right)$ groups favors the migration and coalescence of $\mathrm{Pd}$, whereas in the absence of $\mathrm{H}_{2} \mathrm{O}$, Ostwald ripening is favored. Sintering suppression has been demonstrated for Pt catalysts using supports that enhance metal-support interactions [28]. Nagai et al. [47] demonstrated a correlation between the $\mathrm{O}$ electron density of the support, the strength of the Pt-O interaction and the resulting crystallite size. Thus, supports with a stronger metal-support interaction have a higher $\mathrm{O}$ electron density and yield smaller Pt crystallites in the order $\mathrm{SiO}_{2}<\mathrm{Al}_{2} \mathrm{O}_{3}<\mathrm{ZrO}_{2}<\mathrm{TiO}_{2}<\mathrm{CeO}_{2}$ [28,47].

$\mathrm{Xu}$ et al. [48] reported that the main deactivation mechanism of $\mathrm{Pd} / \mathrm{Al}_{2} \mathrm{O}_{3}$ catalysts following exposure to $10(v / v) \% \mathrm{H}_{2} \mathrm{O} / \mathrm{N}_{2}$ at $900{ }^{\circ} \mathrm{C}$ for up to $200 \mathrm{~h}$ is $\mathrm{Pd}$ sintering. A substantial decrease in $\mathrm{Pd}$ dispersion from $3.7 \%$ to $0.9 \%$ over 7 wt. $\% \mathrm{Pd} / \mathrm{Al}_{2} \mathrm{O}_{3}$ and similar decreases at other Pd loadings after $96 \mathrm{~h}$ hydrothermal aging, were observed. As noted by $\mathrm{Xu}$ et al. [48], aging the catalyst at $900{ }^{\circ} \mathrm{C}$ ensures that $\mathrm{PdO}$ decomposition to $\mathrm{Pd}^{0}$ is complete and consequently the more rapid sintering observed is relevant to the behavior of $\mathrm{Pd}^{0}$ rather than $\mathrm{PdO}$.

Escandon et al. [49] examined effects of hydrothermal aging at lower temperatures, where PdO is thermodynamically stable [6]. A 1 wt.\% $\mathrm{Pd} / \mathrm{ZrO}_{2}-\mathrm{Ce}$ catalyst was hydrothermally aged at 300, 425, and $550{ }^{\circ} \mathrm{C}$ in $2 \% \mathrm{H}_{2} \mathrm{O} /$ Air for $30 \mathrm{~h}$, before being evaluated for $\mathrm{CH}_{4}$ oxidation under lean-burn conditions (5000 ppmv $\mathrm{CH}_{4}$ in dry air). The results, shown in Figure 4, are compared with the same catalyst, thermally aged at $550{ }^{\circ} \mathrm{C}$ in dry air for $30 \mathrm{~h}$ (identified as $\mathrm{Pd} / \mathrm{ZrO}_{2}-\mathrm{Ce}-550$ in Figure 4) [49]. A significant irreversible decrease in $\mathrm{CH}_{4}$ conversion occurs and the extent of catalyst deactivation increases with aging temperature (Figure 4). The $T_{50 \%}$ increases from $375{ }^{\circ} \mathrm{C}$ for the fresh oxidized catalyst (identified as $\mathrm{Pd} / \mathrm{ZrO}_{2}-\mathrm{Ce}$ in Figure 4), to $450{ }^{\circ} \mathrm{C}$ for the air-aged catalyst and to $>550{ }^{\circ} \mathrm{C}$ for the hydrothermally aged catalyst. Pd dispersion and BET surface area of the aged catalysts did not change [49]. Comparing the activity results of the catalyst thermally aged in air $\left(\mathrm{Pd} / \mathrm{ZrO}_{2}-\mathrm{Ce}-550\right)$ with that aged in $2 \% \mathrm{H}_{2} \mathrm{O} /$ air at $550{ }^{\circ} \mathrm{C}\left(\mathrm{Pd} / \mathrm{ZrO}_{2}-\mathrm{Ce}-550 \mathrm{~h}\right)$, confirms that catalyst deactivation rate increases in the presence of $\mathrm{H}_{2} \mathrm{O}$. The stability of the hydrothermally aged catalysts during reaction was also evaluated, using both isothermal deactivation experiments at $500{ }^{\circ} \mathrm{C}$ and light-off measurements made after $50 \mathrm{~h}$ reaction with $5000 \mathrm{ppmv} \mathrm{CH}_{4}$ in air. The catalysts aged in the presence 
of $\mathrm{H}_{2} \mathrm{O}$ at $300{ }^{\circ} \mathrm{C}$ underwent a significant deactivation whereas the catalyst aged in the presence of $\mathrm{H}_{2} \mathrm{O}$ at $425{ }^{\circ} \mathrm{C}$ was much more resistant to deactivation, and after $25 \mathrm{~h}$ time-on-stream was the most active of all the catalysts examined. XRD analysis of the catalysts showed that the more stable catalysts are associated with the most stable supports [49].

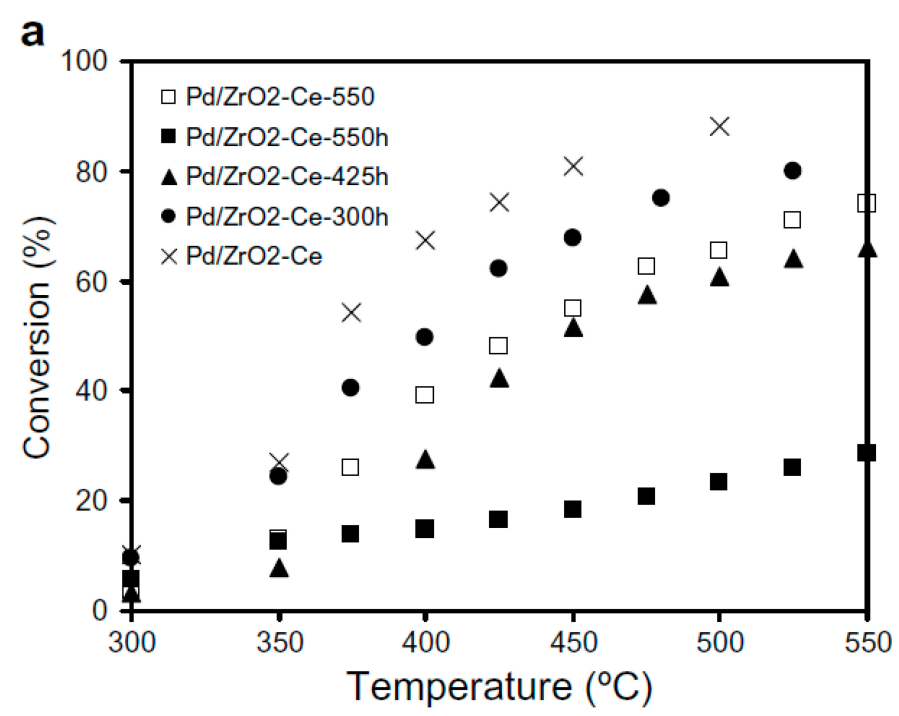

Figure 4. $\mathrm{CH}_{4}$ conversion over fresh $1 \mathrm{wt} . \% \mathrm{Pd} / \mathrm{ZrO}_{2}-\mathrm{Ce}$ catalyst compared to $1 \mathrm{wt} . \%$ $\mathrm{Pd} / \mathrm{ZrO}_{2}-\mathrm{Ce}$ thermally aged in air at $550{ }^{\circ} \mathrm{C}\left(\mathrm{Pd} / \mathrm{ZrO}_{2}-\mathrm{Ce}-550\right)$ and hydrothermally aged at different temperatures in $2 \% \mathrm{H}_{2} \mathrm{O}$ /air (identified as $\mathrm{Pd} / \mathrm{ZrO}_{2}-\mathrm{Ce}-\mathrm{TTTh}$ where TTT is the aging temperature in ${ }^{\circ} \mathrm{C}$ ). Reproduced with permission from [49]. Copyright $(2) 2008$ Elsevier.

In another study of $\mathrm{CH}_{4}$ oxidation at low temperature $\left(250-450{ }^{\circ} \mathrm{C}\right)$, a change in $\mathrm{PdO}$ dispersion was suggested as the main cause of deactivation of $0.5 \% \mathrm{Pd} / \mathrm{Al}_{2} \mathrm{O}_{3}$ and $0.5 \% \mathrm{Pd} / \mathrm{SiO}_{2}$ catalysts [50]. Dispersion decreased from $10 \%$ for the unused $0.5 \% \mathrm{Pd} / \mathrm{SiO}_{2}$ catalyst to $5.6 \%$ for the catalyst reacted in $1 \% \mathrm{CH}_{4} /$ air feed at $450{ }^{\circ} \mathrm{C}$ for $7 \mathrm{~h}$, whereas for the $0.5 \% \mathrm{Pd} / \mathrm{Al}_{2} \mathrm{O}_{3}$ catalyst the corresponding changes in dispersion were $67 \%$ to $6.3 \%$, respectively. These observations are in good agreement with that of Narui et al. [51], in which the $\mathrm{PdO}$ dispersion of a $0.5 \% \mathrm{Pd} / \mathrm{Al}_{2} \mathrm{O}_{3}$ catalyst decreased from $14 \%$ to $11 \%$ after $6 \mathrm{~h}$ reaction at $350{ }^{\circ} \mathrm{C}$. Zhang et al. [52] investigated Pd catalysts supported on ZSM-5 and reported that catalyst stability is improved when $\mathrm{CH}_{4}$ oxidation is carried out in the presence of $\mathrm{H}_{2} \mathrm{O}$ at $430-480{ }^{\circ} \mathrm{C}$, compared to the reaction in a dry feed. In both cases, the loss in catalyst activity could be related to reduced $\mathrm{PdO}$ dispersion, as determined by the $\mathrm{Pd} / \mathrm{Si}$ ratio measured by XPS, but the loss in dispersion is smaller in the presence of $\mathrm{H}_{2} \mathrm{O}$ [52]. By contrast, Araya et al. [53] reported an insignificant drop in $\mathrm{PdO}$ dispersion (from $31.7 \%$ to $28.2 \%$ ) of a $\mathrm{Pd} / \mathrm{SiO}_{2}$ catalyst after $96 \mathrm{~h}$ of reaction at $325{ }^{\circ} \mathrm{C}$ in $1.5 \% \mathrm{CH}_{4} / 6 \% \mathrm{O}_{2}$ in $\mathrm{He}$, despite a significant decrease in $\mathrm{CH}_{4}$ conversion from $32 \%$ to $22 \%$. The extent of catalyst deactivation was found to further increase in the presence of $3 \% \mathrm{H}_{2} \mathrm{O}$ added to the feed.

Several studies have demonstrated that catalyst sintering can be reduced by encapsulating $\mathrm{Pd} / \mathrm{PdO}$ nanoparticles in support materials. Sinter-resistant Pd catalysts have been prepared by atomic layer deposition of $\mathrm{Al}_{2} \mathrm{O}_{3}$ overlayers on $\mathrm{Pd}$ [54], as well as by the synthesis of $\mathrm{Pd} / \mathrm{SiO}_{2}$ core-shell structures [55,56]. Cargnello et al. [22] reported a $\mathrm{Pd} / \mathrm{CeO}_{2}$ core-shell catalyst supported on $\mathrm{Al}_{2} \mathrm{O}_{3}$ for $\mathrm{CH}_{4}$ oxidation that is about $200 x$ s more active than an equivalent $\mathrm{Pd}-\mathrm{CeO}_{2} / \mathrm{Al}_{2} \mathrm{O}_{3}$ catalyst prepared by 
wet impregnation. The authors demonstrated that the Pd cores remain isolated even after heating the catalyst to $850{ }^{\circ} \mathrm{C}$ and that the $\mathrm{CH}_{4}$ light-off curves (measured at GHSV of 200,000 $\mathrm{h}^{-1}$ in a feed gas of $0.5 \% \mathrm{CH}_{4}, 2 \% \mathrm{O}_{2}$ in $\mathrm{Ar}$ ) are the same for the fresh catalyst and one that has been aged at $850{ }^{\circ} \mathrm{C}$ for 12 hours. The $\mathrm{Pd}$ nanoparticles encapsulated by $\mathrm{CeO}_{2}$ enhance the metal-support interaction that leads to exceptionally high $\mathrm{CH}_{4}$ oxidation activity and good thermal stability [22].

\subsection{Effects of Support}

The data of Table 1 show that the inhibition of $\mathrm{CH}_{4}$ oxidation by $\mathrm{H}_{2} \mathrm{O}$ on $\mathrm{Pd}$ catalysts is dependent upon the support. $\mathrm{Pd} / \mathrm{Al}_{2} \mathrm{O}_{3}$ shows significantly more inhibition with $10 \% \mathrm{H}_{2} \mathrm{O}$ added to the feed than either the $\mathrm{Pd} / \mathrm{SnO}_{2}$ or $\mathrm{Pd} / \mathrm{ZrO}_{2}$ catalysts. More detailed data from Kikuchi et al. [16] comparing $\mathrm{CH}_{4}$ light-off curves for a $1.1 \mathrm{wt} . \% \mathrm{Pd} / \mathrm{Al}_{2} \mathrm{O}_{3}$ catalyst and a $1.1 \mathrm{wt} . \% \mathrm{Pd} / \mathrm{SnO}_{2}$ catalyst with $\mathrm{H}_{2} \mathrm{O}$ added to the feed over a range of concentrations (1-20 vol.\%), are shown in Figures 5 and 6. By increasing the $\mathrm{H}_{2} \mathrm{O}$ concentration, the $\mathrm{CH}_{4}$ light-off curves for both catalysts shift to higher temperatures. However, the temperature shift is larger over the $\mathrm{Pd} / \mathrm{Al}_{2} \mathrm{O}_{3}$ catalyst than the $\mathrm{Pd} / \mathrm{SnO}_{2}$. The authors completed a simplified kinetic analysis of the $\mathrm{CH}_{4}$ oxidation rate data to show that the enthalpy of adsorption of $\mathrm{H}_{2} \mathrm{O}$ is strongest on the $\mathrm{Pd} / \mathrm{Al}_{2} \mathrm{O}_{3}$ catalyst $\left(\Delta \mathrm{H}_{\mathrm{ad}} \sim-49 \mathrm{~kJ} / \mathrm{mol}\right)$, from which they concluded that the significant loss in activity of the $\mathrm{Pd} / \mathrm{Al}_{2} \mathrm{O}_{3}$ in the presence of $\mathrm{H}_{2} \mathrm{O}$ is due to a high coverage of the active sites by $\mathrm{H}_{2} \mathrm{O}$ [16]. These results could also be interpreted according to the more recent proposals by Schwartz et al. [44,57], that hydroxyl accumulation on the support hinders oxygen migration and exchange, and hence $\mathrm{CH}_{4}$ oxidation. The strong adsorption of $\mathrm{H}_{2} \mathrm{O}$ determined by kinetic analysis on the $\mathrm{Pd} / \mathrm{Al}_{2} \mathrm{O}_{3}$ catalyst [16] is consistent with a large hydroxyl accumulation on the catalyst surface that could inhibit the $\mathrm{O}$ exchange.

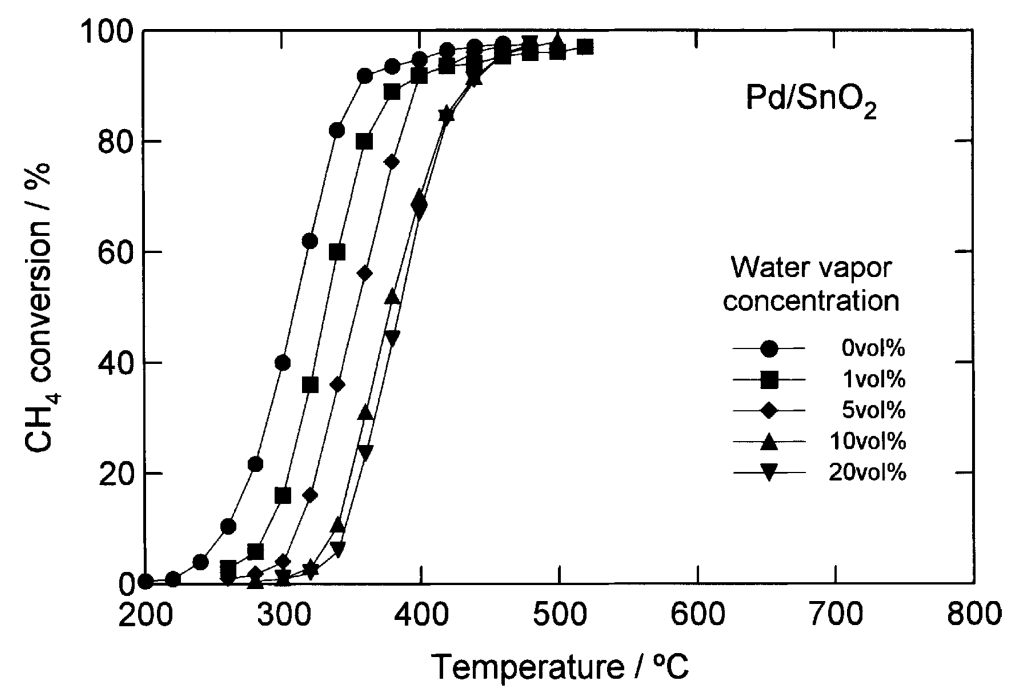

Figure 5. Catalytic combustion of $\mathrm{CH}_{4}$ over $1.1 \mathrm{wt} . \% \mathrm{Pd} / \mathrm{SnO}_{2}$ with different amounts of water added (vol.\%). Reaction conditions: $\mathrm{CH}_{4}, 1$ vol.\%; $\mathrm{O}_{2}, 20$ vol.\%; $\mathrm{H}_{2} \mathrm{O}, 0-20$ vol.\%; $\mathrm{N}_{2}$, balance; GHSV 48,000 h ${ }^{-1}$. Reprinted with permission from [16]. Copyright $\odot 2002$ Elsevier. 


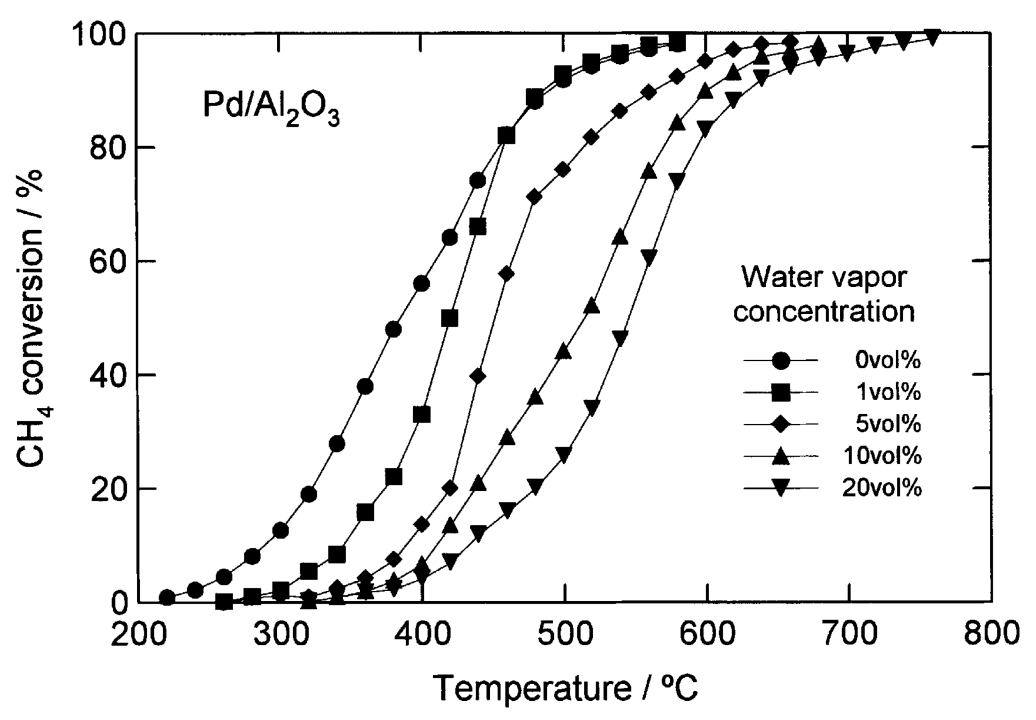

Figure 6. Catalytic combustion of $\mathrm{CH}_{4}$ over 1.1 wt. $\% \mathrm{Pd} / \mathrm{Al}_{2} \mathrm{O}_{3}$ with different amounts of water added (vol.\%). Reaction conditions: $\mathrm{CH}_{4}, 1$ vol.\%; $\mathrm{O}_{2}, 20$ vol.\%; $\mathrm{H}_{2} \mathrm{O}, 0-20$ vol.\%; $\mathrm{N}_{2}$, balance; GHSV 48,000 $\mathrm{h}^{-1}$. Reprinted with permission from [16]. Copyright (C) 2002 Elsevier.

The rate of deactivation during $\mathrm{CH}_{4}$ oxidation in the presence of $\mathrm{H}_{2} \mathrm{O}$ has been shown to be reduced by using a support with high oxygen surface mobility. At temperatures below $450{ }^{\circ} \mathrm{C}$, Ciuparu et al. [30] reported the inhibition effect of $\mathrm{H}_{2} \mathrm{O}$ to be dependent upon the oxygen mobility of the support. Comparing $\mathrm{PdO}$ supported on oxides with increasing surface oxygen mobility: $\mathrm{Al}_{2} \mathrm{O}_{3}<\mathrm{ZrO}_{2}<$ $\mathrm{Ce}_{0.1} \mathrm{Zr}_{0.9} \mathrm{O}_{2}$, they show that the resistance to $\mathrm{H}_{2} \mathrm{O}$ inhibition during $\mathrm{CH}_{4}$ oxidation increases in the same order. The deactivation rate of $\mathrm{PdO}$ was also compared over $\mathrm{Al}_{2} \mathrm{O}_{3}, \mathrm{MgO}$, and $\mathrm{TiO}_{2}$ supports by Schwartz et al. $[44,57]$ at temperatures $<450{ }^{\circ} \mathrm{C}$. Deactivation is shown to be a consequence of reduced oxygen mobility due to hydroxyl adsorption. They also reported that $\mathrm{PdO} / \mathrm{MgO}$ catalyst has a slower deactivation rate compared with $\mathrm{Al}_{2} \mathrm{O}_{3}$ and $\mathrm{TiO}_{2}$ supports because of the higher oxygen surface mobility on the $\mathrm{MgO}[44,57]$. However, Pd catalysts dispersed on other supports such as MCM-41, which have high surface area $\left(1113 \mathrm{~m}^{2} / \mathrm{g}\right)$ and lower oxygen mobility than $\mathrm{MgO}$ and $\mathrm{Al}_{2} \mathrm{O}_{3}$, did not deactivate either, suggesting that other factors also play a role, depending on the catalyst and the support.

Another study compared the stability of $\mathrm{Pd} / \mathrm{SiO}_{2}$ and $\mathrm{Pd} / \mathrm{ZrO}_{2}$ during $\mathrm{CH}_{4}$ oxidation using a dry feed gas [53]. The data (Figure 7) show that the $\mathrm{Pd} / \mathrm{ZrO}_{2}$ is stable after $40 \mathrm{~h}$ time-on-stream, while the $\mathrm{CH}_{4}$ conversion over the $\mathrm{Pd} / \mathrm{SiO}_{2}$ catalyst increases from $13 \%$ to $32 \%$ in the first $3 \mathrm{~h}$, and then decreases to $22 \%$ after $96 \mathrm{~h}$ (see Figure 7). Although the $\mathrm{Pd} / \mathrm{ZrO}_{2}$ catalyst is more stable than the $\mathrm{Pd} / \mathrm{SiO}_{2}$ catalyst, its conversion is lower than for the $\mathrm{Pd} / \mathrm{SiO}_{2}$ catalyst. The lower deactivation rate observed on the $\mathrm{Pd} / \mathrm{ZrO}_{2}$ is consistent with the higher oxygen mobility of this catalyst compared to $\mathrm{Pd} / \mathrm{SiO}_{2}$, as noted above.

Metal-support interactions, support stability and the tendency of the support to encapsulate Pd, may also play a role in the deactivation of $\mathrm{Pd}$ catalysts during $\mathrm{CH}_{4}$ oxidation. Gannouni et al. [58] compared Pd catalysts supported on silica and mesoporous aluminosilicas and showed that, according to the light-off curves measured with $1 \% \mathrm{CH}_{4}, 4 \% \mathrm{O}_{2}$ in $\mathrm{He}, \mathrm{CH}_{4}$ oxidation activity is enhanced on the pure silica support, whereas on the aluminosilica, the beneficial effect of $\mathrm{Al}^{3+}$ on metal dispersion and catalytic activity is counterbalanced by partial metal encapsulation. Above $500{ }^{\circ} \mathrm{C}$ in the presence of $\mathrm{H}_{2} \mathrm{O}$, the structural collapse of the support, metal sintering, and metal encapsulation by the support all 
occur [58]. Similar effects were reported with $\mathrm{SiO}_{2}$ supports by $\mathrm{Zhu}$ et al. [59]. $\mathrm{SiO}_{2}$ desorbs chemisorbed $\mathrm{H}_{2} \mathrm{O}$ (silanol groups $-\mathrm{Si}-\mathrm{OH}$ ) at $\sim 397^{\circ} \mathrm{C}$ [46] and the formation of hydroxides according to the reaction: $\mathrm{SiO}_{2(\mathrm{~s})}+2 \mathrm{H}_{2} \mathrm{O}_{(\mathrm{g})} \leftrightarrow \mathrm{Si}(\mathrm{OH})_{4(\mathrm{~g})}$ is feasible at temperatures above $700{ }^{\circ} \mathrm{C}[60,61]$. Hydroxyl mobility can change the extent of metal-support interactions [45,46]. Zhu et al. [59] reported the encapsulation of $\mathrm{PdO}$ by $\mathrm{SiO}_{2}$ during $\mathrm{CH}_{4}$ oxidation at only $325{ }^{\circ} \mathrm{C}$. The authors suggested that silica migration by (i) formation of a palladium silicide during $\mathrm{H}_{2}$ reduction at $650{ }^{\circ} \mathrm{C}$ that is subsequently oxidized during $\mathrm{CH}_{4}$ oxidation and (ii) migration of $\mathrm{SiO}_{2}$ during $\mathrm{CH}_{4}$ oxidation caused by the water formed during reaction, are important related factors facilitating the encapsulation of PdO by the $\mathrm{SiO}_{2}$. Migration of $\mathrm{SiO}_{2}$ onto the metal crystallites in other catalyst systems containing $\mathrm{H}_{2} \mathrm{O}$ has also been reported in the literature $[46,62]$.

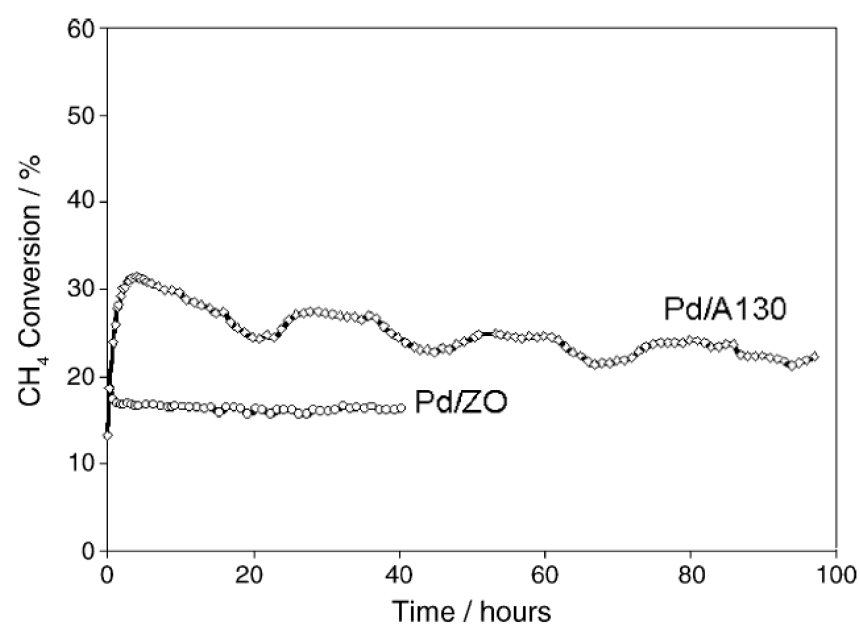

Figure 7. Methane conversion over time of $\mathrm{Pd} / \mathrm{ZrO}_{2}$ and $\mathrm{Pd} /$ Aerosil130 catalysts. Reaction conditions: $1.5 \% \mathrm{CH}_{4} ; 6 \% \mathrm{O}_{2}$; total flow $=90 \mathrm{~cm}^{3} \mathrm{~min}^{-1}$, balanced in He; temperature $=325{ }^{\circ} \mathrm{C}$; catalyst mass $=0.2 \mathrm{~g}$. Reprinted with permission from [53]. Copyright (C) 2005 Elsevier.

Yoshida et al. [63] also examined the effects of various metal oxide supports of Pd on the low temperature oxidation of $\mathrm{CH}_{4}$ as summarized in Table 3. The catalytic activity varies with the support, but the support oxides with moderate acid strength $\left(\mathrm{Al}_{2} \mathrm{O}_{3}\right.$ and $\left.\mathrm{SiO}_{2}\right)$ give maximum $\mathrm{CH}_{4}$ conversion. For these catalysts higher activity corresponds to a higher oxidation state of $\mathrm{Pd}$ (bulk $\mathrm{PdO}$ ). The lower activity of $\mathrm{Pd}$ on basic supports is attributed to the formation of binary oxides from $\mathrm{PdO}$ and the support (such as $\mathrm{Pd} / \mathrm{MgO}_{x}$ ), in spite of a high $\mathrm{Pd}$ oxidation state.

The effect of metal oxides added to $\mathrm{Pd} / \mathrm{Al}_{2} \mathrm{O}_{3}$ to improve the hydrothermal stability has been reported by Liu et al. [36] who showed in particular, that the addition of $\mathrm{NiO}$ or $\mathrm{MgO}$ improved the hydrothermal stability of $\mathrm{Pd} / \mathrm{Al}_{2} \mathrm{O}_{3}$ through the formation of $\mathrm{NiAl}_{2} \mathrm{O}_{4}$ and $\mathrm{MgAl}_{3} \mathrm{O}_{4}$ spinel structures. According to the authors, the spinel results in weakened support acidity that suppresses the formation of $\mathrm{Pd}(\mathrm{OH})_{2}$ during hydrothermal aging. 
Table 3. Effect of support on properties of 5 wt.\% Pd catalysts and their $\mathrm{CH}_{4}$ oxidation conversion. Data adapted from [63].

\begin{tabular}{ccccc}
\hline Support & Support Acid Strength & \multicolumn{2}{c}{ Pd Dispersion } & $\begin{array}{c}\mathbf{C H}_{4} \text { conversion } \\
\text { \% }\end{array}$ \\
\hline $\mathrm{MgO}$ & $\left(\mathrm{H}_{\mathrm{o}}\right)$ & Fresh & Used \\
$\mathrm{ZrO}$ & 22.3 & 0.21 & 0.20 & 12 \\
$\mathrm{Al}_{2} \mathrm{O}_{3}$ & 9.3 & 0.41 & 0.12 & 3 \\
$\mathrm{SiO}_{2}$ & 3.3 & 0.35 & 0.20 & 59 \\
$\mathrm{SiO}_{2}-\mathrm{ZrO}_{2}$ & -5.6 & 0.09 & 0.11 & 58 \\
$\mathrm{SiO}_{2}-\mathrm{Al}_{2} \mathrm{O}_{3}$ & -8.2 & 0.16 & 0.13 & 20 \\
$\mathrm{SO}_{4}{ }^{2-}-\mathrm{ZrO}_{2}$ & -11.9 & 0.12 & 0.06 & 10 \\
\hline
\end{tabular}

${ }^{\text {a }}$ measured at $350{ }^{\circ} \mathrm{C}$ in $0.25 \% \mathrm{CH}_{4} / 3 \% \mathrm{O}_{2}$ in $\mathrm{He}$ at $\mathrm{GHSV}$ of $1,200,000 \mathrm{~h}^{-1}$.

A comparison of initial $\mathrm{CH}_{4}$ oxidation activity as a function of temperature for Pd-Pt catalysts on $\mathrm{Al}_{2} \mathrm{O}_{3}, \mathrm{ZrO}_{2}, \mathrm{LaMnAl}_{11} \mathrm{O}_{19}, \mathrm{Ce}-\mathrm{ZrO}_{2}$, and $\mathrm{Y}-\mathrm{ZrO}_{2}$ was reported by Persson et al. [64]. Monolith catalysts were tested in a tubular quartz flow reactor at atmospheric pressure in 1.5 vol.\% $\mathrm{CH}_{4}$ in dry air and at a space velocity of $250,000 \mathrm{~h}^{-1}$. In steady-state experiments, reaction temperature was set initially at $470{ }^{\circ} \mathrm{C}$ and then increased to $720^{\circ} \mathrm{C}$ stepwise in $50{ }^{\circ} \mathrm{C}$ increments, with 1 -h holds at each temperature. The $\mathrm{Pd}-\mathrm{Pt} / \mathrm{Al}_{2} \mathrm{O}_{3}$ catalyst had the highest activity at lower temperatures $\left(470-570{ }^{\circ} \mathrm{C}\right)$, while the $\mathrm{Pd}-\mathrm{Pt} / \mathrm{Ce}-\mathrm{ZrO}_{2}$ catalyst had the highest activity between $620^{\circ} \mathrm{C}$ and $800{ }^{\circ} \mathrm{C}$ [64]. The authors suggested that the higher surface area of the $\mathrm{Al}_{2} \mathrm{O}_{3}$ compared to the other supports (e.g., $90 \mathrm{~m}^{2} / \mathrm{g}$ for $\mathrm{Al}_{2} \mathrm{O}_{3}$ versus $10 \mathrm{~m}^{2} / \mathrm{g}$ for $\mathrm{Ce}-\mathrm{ZrO}_{2}$ ) accounts for the higher activity of $\mathrm{Pd}-\mathrm{Pt} / \mathrm{Al}_{2} \mathrm{O}_{3}$ at lower temperatures, due to higher dispersion of $\mathrm{Pd}-\mathrm{Pt}$ oxides, while at higher reaction temperatures the $\mathrm{Pd}-\mathrm{Pt}$ catalyst probably undergoes reduction to the metal. A combination of lower activity for Pd metal and its propensity for rapid sintering probably explain the lower activity. The authors also suggested that the $\mathrm{Ce}-\mathrm{ZrO}_{2}$ likely enhances the stability of the $\mathrm{PdO}$, similar to the enhanced stability observed on $\mathrm{CeO}_{2}$ [30]. In addition, $\mathrm{ZrO}_{2}$ has high oxygen mobility [30] and the ability to re-oxidize metallic $\mathrm{Pd}$ into PdO should be higher. Indeed, Pd/alumina is re-oxidized very slowly, whereas Pd supported on ceria-stabilized $\mathrm{ZrO}_{2}$, is re-oxidized more rapidly.

Since $\mathrm{H}_{2} \mathrm{O}$ adsorption on the $\mathrm{Pd}$ and/or the support is an important step in inhibiting $\mathrm{CH}_{4}$ oxidation over $\mathrm{Pd}$, support hydrophobicity may be expected to impact the inhibition effect of $\mathrm{H}_{2} \mathrm{O}$. Araya et al. [53] studied this effect on the deactivation of Pd-based catalysts by preparing $1 \mathrm{wt} . \% \mathrm{Pd}$ on two different commercial silicas, Aerosil130 and Aerosil R972. The Aerosil R972 is hydrophobic since the OH groups have been replaced by methyl groups. Both $1 \% \mathrm{Pd} / \mathrm{A} 130$ and $1 \% \mathrm{Pd} / \mathrm{R} 972$ were tested at $325{ }^{\circ} \mathrm{C}$ in a gaseous mixture of $1.5 \% \mathrm{CH}_{4}$ and $6 \% \mathrm{O}_{2}$ in $\mathrm{He}$ at a total flow rate of $90 \mathrm{~cm}^{3} \mathrm{~min}^{-1}$ with addition of $3 \% \mathrm{H}_{2} \mathrm{O}$ after $2 \mathrm{~h}$ As shown in Figure 8, the effect of $\mathrm{H}_{2} \mathrm{O}$ addition to the feed gas is 
approximately the same for the hydrophobic silica, $\mathrm{Pd} / \mathrm{R} 972$, and the hydrophilic $\mathrm{Pd} / \mathrm{A} 130$. In both cases, a large decrease in $\mathrm{CH}_{4}$ conversion is observed with the introduction of $\mathrm{H}_{2} \mathrm{O}$ to the reactor. The authors reported a reaction order with respect to $\mathrm{H}_{2} \mathrm{O}$ of -0.25 for both $\mathrm{Pd} / \mathrm{A} 130$ and $\mathrm{Pd} / \mathrm{R} 972$, emphasizing that the hydrophobicity of the support does not affect the extent of $\mathrm{H}_{2} \mathrm{O}$ inhibition observed on either catalyst.
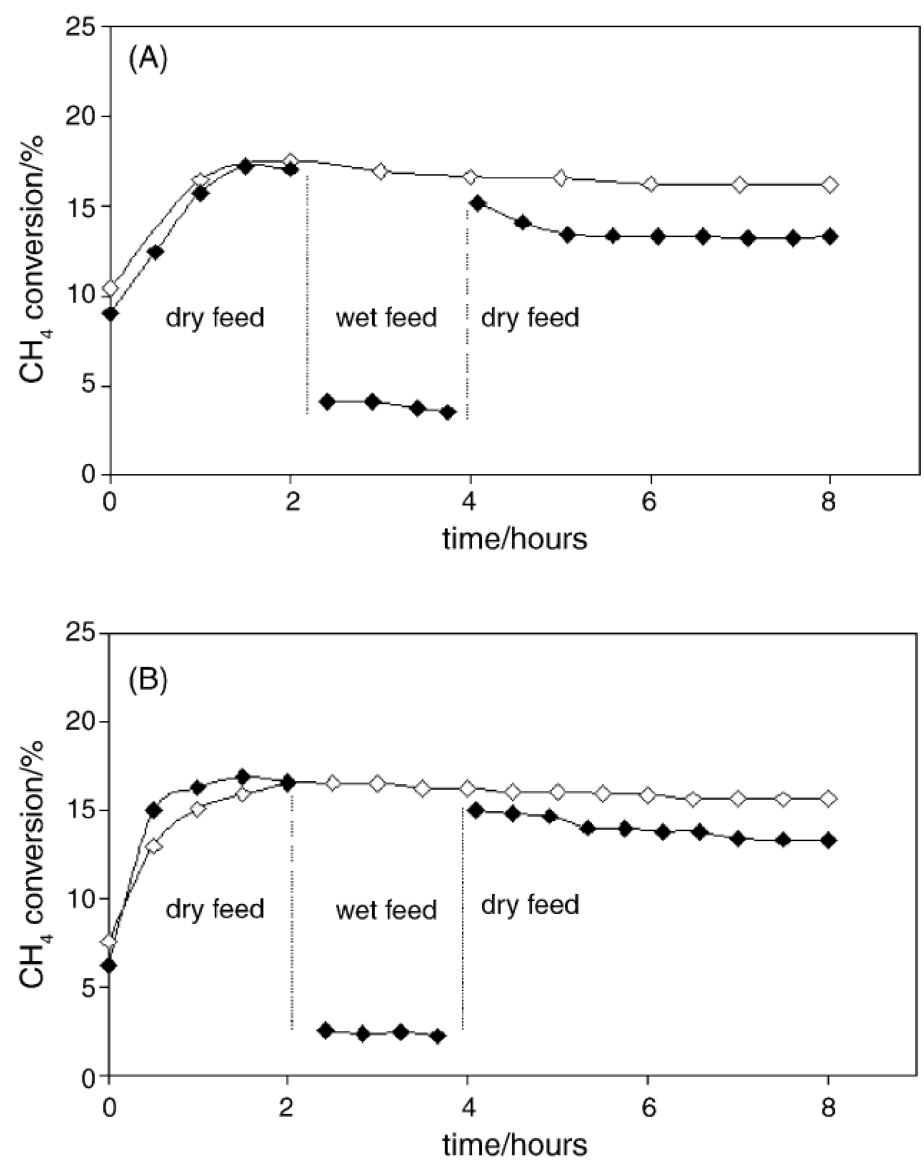

Figure 8. (A) Pd/Aerosil130 catalyst, (B) Pd/R972 catalyst. Reaction conditions: total flow $=90 \mathrm{~cm}^{3}(\mathrm{STP}) \mathrm{min}^{-1}$, temperature $=325{ }^{\circ} \mathrm{C}$; catalyst mass $=0.2 \mathrm{~g}$. Open symbols: dry feed $1.5 \% \mathrm{CH}_{4} ; 6 \% \mathrm{O}_{2}$; balance $\mathrm{He}$; closed symbol: wet feed $1.5 \% \mathrm{CH}_{4} ; 6 \% \mathrm{O}_{2}$ with $3 \%$ $\mathrm{H}_{2} \mathrm{O}$, balance He. Reproduced with permission from [53]. Copyright (C) 2005 Elsevier.

\section{4. $\mathrm{H}_{2} \mathrm{O}$ Inhibition and Hydroxyl Formation}

Although $\mathrm{Pd}(\mathrm{OH})_{2}$ has been postulated as a cause for deactivation of $\mathrm{PdO}$ catalysts in the presence of $\mathrm{H}_{2} \mathrm{O}[18,31,32,40]$, and while this mechanism is consistent with many of the observations discussed above, recent evidence obtained from FTIR and isotopic labeling experiments that monitor the formation and conversion of hydroxyls on the catalyst surface during reaction, suggest an alternative mechanism of deactivation.

Using DRIFTS, Persson et al. [35] reported an increase in signal intensity from surface hydroxyls weakly H-bonded to the support (3200-3800 $\mathrm{cm}^{-1}$ ) [65] after introducing $1.5 \% \mathrm{CH}_{4}$ in air to a $\mathrm{PdO} / \mathrm{Al}_{2} \mathrm{O}_{3}$ catalyst at low temperature $\left(200{ }^{\circ} \mathrm{C}\right.$; Figure 9$)$. The peak at $3016 \mathrm{~cm}^{-1}$ in Figure $9 \mathrm{a}$, assigned to gas phase $\mathrm{CH}_{4}$, increases with time-on-stream because of catalyst deactivation. The hydroxyls have characteristic adsorptions at $3733,3697,3556$ and $3500 \mathrm{~cm}^{-1}$, with the hydroxyls at 3697 and $3733 \mathrm{~cm}^{-1}$ 
assigned to bridged and terminal isolated hydroxyl species, respectively. Upon $\mathrm{CH}_{4}$ removal from the feed (Figure 9b), the peaks associated with $\mathrm{OH}$ species remain, highly consistent with a slow desorption of $\mathrm{OH}$ species produced during $\mathrm{CH}_{4}$ oxidation. Hence, Persson et al. [35] suggested that catalyst deactivation on $\mathrm{PdO} / \mathrm{Al}_{2} \mathrm{O}_{3}$ might be due to the formation and accumulation of hydroxyls on the catalyst surface, bound either to the $\mathrm{PdO}, \mathrm{Al}_{2} \mathrm{O}_{3}$ or the interface between the two [30]. Gao et al. [32] reported similar hydroxyl bands at 3733, 3697, 3556 and $3500 \mathrm{~cm}^{-1}$ during lean-burn $\mathrm{CH}_{4}$ oxidation $\left(0.4 \% \mathrm{CH}_{4}\right.$ in air) at $250{ }^{\circ} \mathrm{C}$. The FTIR spectra from reaction with 2 vol.\% $\mathrm{H}_{2} \mathrm{O}$ added to the $\mathrm{CH}_{4}-\mathrm{O}_{2}$ feed also yield a broad band at $3445 \mathrm{~cm}^{-1}$ that is associated with $\mathrm{OH}$ species on $\mathrm{Al}_{2} \mathrm{O}_{3}$ [32].

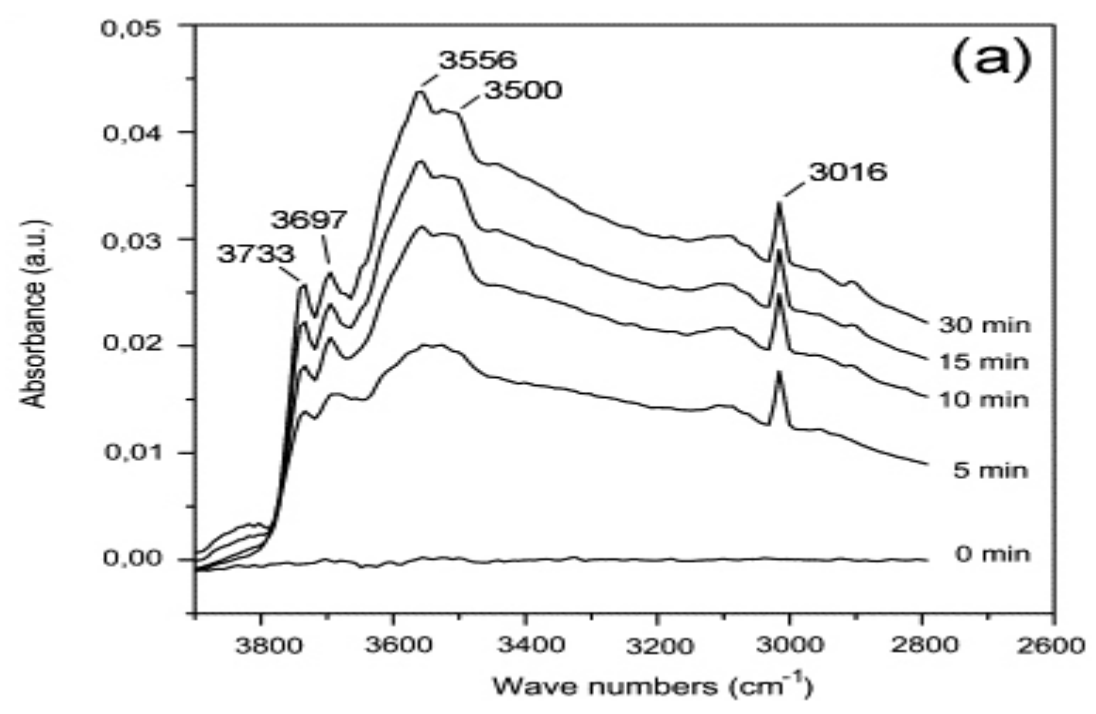

Figure 9. Cont.

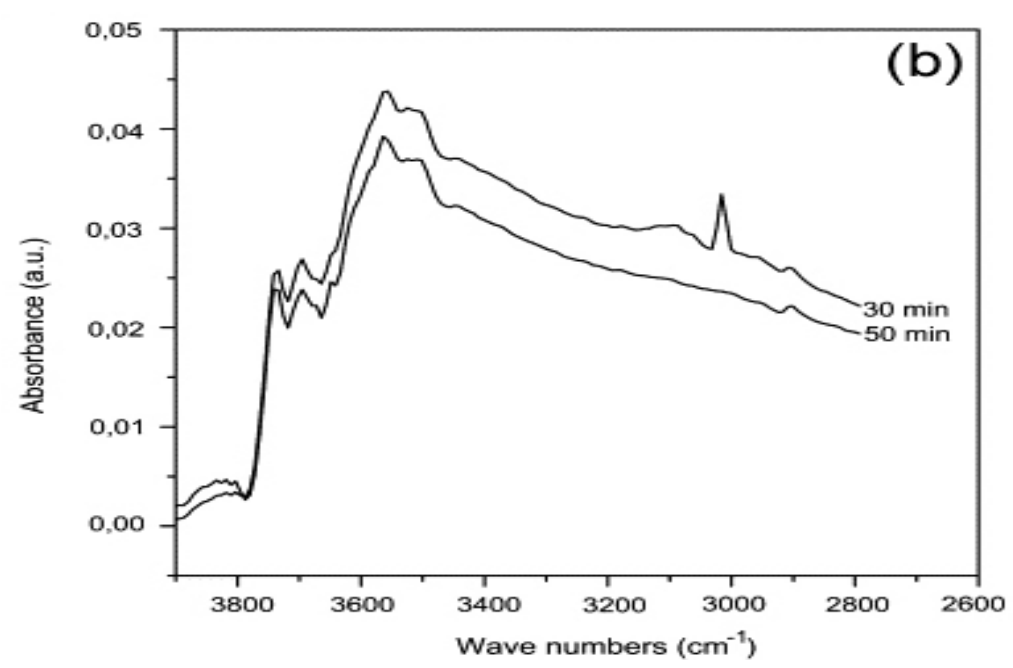

Figure 9. FTIR spectra of 5 wt. $\% \mathrm{Pd} / \mathrm{Al}_{2} \mathrm{O}_{3}$ at $200{ }^{\circ} \mathrm{C}$ (a) during the $\mathrm{CH}_{4}-\mathrm{O}_{2}$ reaction; (b) desorption when $\mathrm{CH}_{4}$ was removed. Reproduced with permission from [35]. Copyright $(\mathrm{C}$ 2007 Elsevier. 


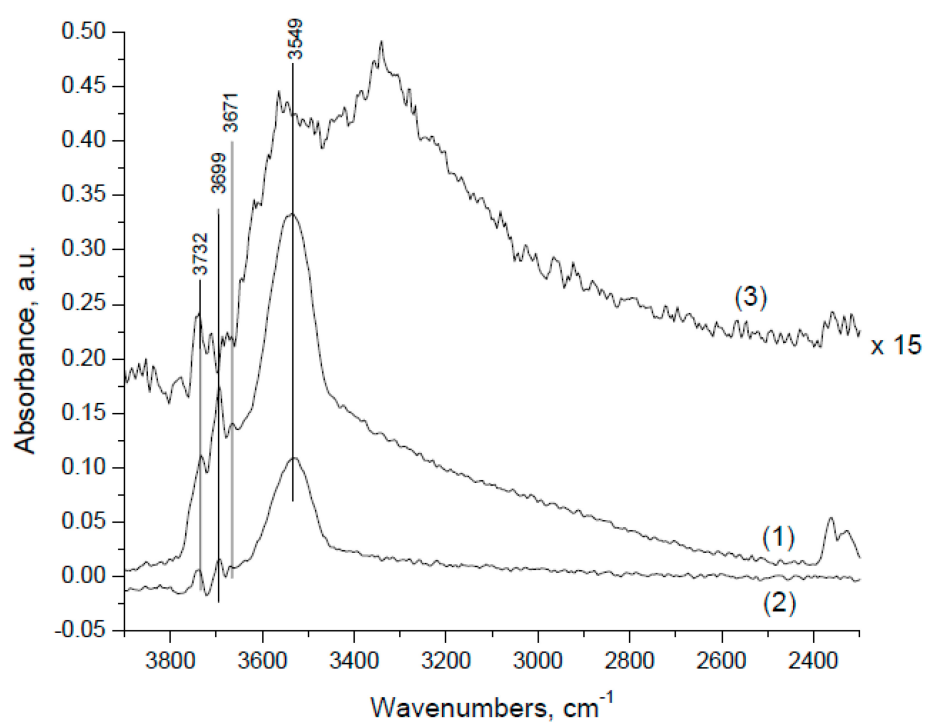

Figure 10. FTIR spectra at highest surface coverage and $350{ }^{\circ} \mathrm{C}$ on (1) $\mathrm{PdO} / \mathrm{Al}_{2} \mathrm{O}_{3}$ during $\mathrm{CH}_{4}-\mathrm{O}_{2}$ reaction, (2) $\mathrm{PdO} / \mathrm{Al}_{2} \mathrm{O}_{3}$ and (3) $\mathrm{Al}_{2} \mathrm{O}_{3}$ when injecting $\mathrm{H}_{2} \mathrm{O}$ pulses. Reproduced with permission from [30]. Copyright (C) 2004 Elsevier.

Ciuparu et al. [30] also identified three well-defined peaks at $3732\left(\mathrm{OH}_{\mathrm{I}}\right), 3699\left(\mathrm{OH}_{\mathrm{II}}\right)$, and $3549\left(\mathrm{OH}_{\mathrm{III}}\right) \mathrm{cm}^{-1}$ associated with surface hydroxyls generated during $\mathrm{CH}_{4}$ oxidation on a $\mathrm{PdO} / \mathrm{Al}_{2} \mathrm{O}_{3}$ catalyst $\left(3.5 \mathrm{wt} \% \mathrm{Pd}\right.$ ) at $350{ }^{\circ} \mathrm{C}$ using a feed gas of $0.128 \% \mathrm{CH}_{4}$ and $17.3 \% \mathrm{O}_{2}$ in $\mathrm{He} / \mathrm{N}_{2}$ (Figure 10). The spectrum was compared to that measured at the same temperature when injecting pulses of $\sim 3 \%$ $\mathrm{H}_{2} \mathrm{O}$ into an air flow over the $\mathrm{PdO} / \mathrm{Al}_{2} \mathrm{O}_{3}$ catalyst and the $\mathrm{Al}_{2} \mathrm{O}_{3}$ support (see Figure 10). Since $\mathrm{Al}_{2} \mathrm{O}_{3}$ has been shown to have a significantly lower hydroxyl coverage compared to $\mathrm{PdO} / \mathrm{Al}_{2} \mathrm{O}_{3}$ when injecting $\mathrm{H}_{2} \mathrm{O}$ pulses at $350{ }^{\circ} \mathrm{C}$ (the spectrum of $\mathrm{Al}_{2} \mathrm{O}_{3}$ is magnified by a factor of 15 in Figure 10), they concluded that the three peaks are associated with the presence of $\mathrm{OH}$ adsorbed on the $\mathrm{PdO}$ catalyst surface. The higher hydroxyl coverage during $\mathrm{CH}_{4}$ oxidation compared to pulse injection of $\mathrm{H}_{2} \mathrm{O}$ onto the $\mathrm{PdO} / \mathrm{Al}_{2} \mathrm{O}_{3}$ catalyst, indicates that (1) adsorbed $\mathrm{H}_{2} \mathrm{O}$ is dissociated on the surface of $\mathrm{PdO} / \mathrm{Al}_{2} \mathrm{O}_{3}$ and (2) hydroxyls formed from $\mathrm{H}_{2} \mathrm{O}$ pulses are less strongly bound to the surface than hydroxyls produced by the $\mathrm{CH}_{4}$ oxidation reaction.

Since the frequencies of the $\mathrm{OH}_{\mathrm{I}}$ and $\mathrm{OH}_{\mathrm{II}}$ species are shifted to higher wave numbers for $\mathrm{OH}$ species more weakly bound to Pd, Ciuparu et al. [30] suggested that the high frequency peaks $\left(\mathrm{OH}_{\mathrm{I}}\right.$, $\mathrm{OH}_{\text {II }}$ ) can be assigned to terminal and bridged hydroxyl species, respectively, and the low frequency peak at $\sim 3549 \mathrm{~cm}^{-1}$ with broad maximum values can be associated with $\mathrm{OH}$ species bound to different sites (multi-bound OHs; OH $\mathrm{OHI}_{\text {II }}$ (Figure 10). Transient temperature experiments show that the hydroxyl binding energy increases in the order $\mathrm{OH}_{\mathrm{I}}<\mathrm{OH}_{\text {II }}<\mathrm{OH}_{\text {III }}[30]$.

The peak areas of the terminal, bridged, and multi-bound hydroxyls were monitored with time-on-stream at different temperatures during reaction, as illustrated by Figure 11 for reaction at 175 ${ }^{\circ} \mathrm{C}$ [30]. Upon removal of $\mathrm{CH}_{4}$ from the feed, the peak areas for the bridged and multi-bound $\mathrm{OH}$ species continue to increase, whereas the area of the terminal $\mathrm{OH}$ species decreases (Figure 11). This decrease is attributed to the conversion of terminal $\mathrm{OH}$ species to bridged or multi-bound $\mathrm{OH}$ species. Based on the intensities of the various hydroxyl species at different temperatures, the authors proposed the inter-conversion among the $\mathrm{OH}$ species as: $\mathrm{OH}_{\mathrm{III}} \leftrightarrow \mathrm{OH}_{\mathrm{II}} \leftrightarrow \mathrm{OH}_{\mathrm{I}} \rightarrow \mathrm{H}_{2} \mathrm{O}_{(\mathrm{g})}$ where only terminal 
$\mathrm{OH}$ species recombine and desorb as $\mathrm{H}_{2} \mathrm{O}$ and the transformation of bridged $\mathrm{OH}$ species to terminal $\mathrm{OH}$ species is the rate determining step (RDS) for hydroxyl desorption and hence low temperature $\mathrm{CH}_{4}$ oxidation [30]. Importantly the authors show that the surface coverage by the hydroxyls (Figure 11) correlates with the activity loss at low temperature, meaning that the activity loss and surface coverage have similar timescales, from which they conclude that the former is likely an effect of the latter [30].

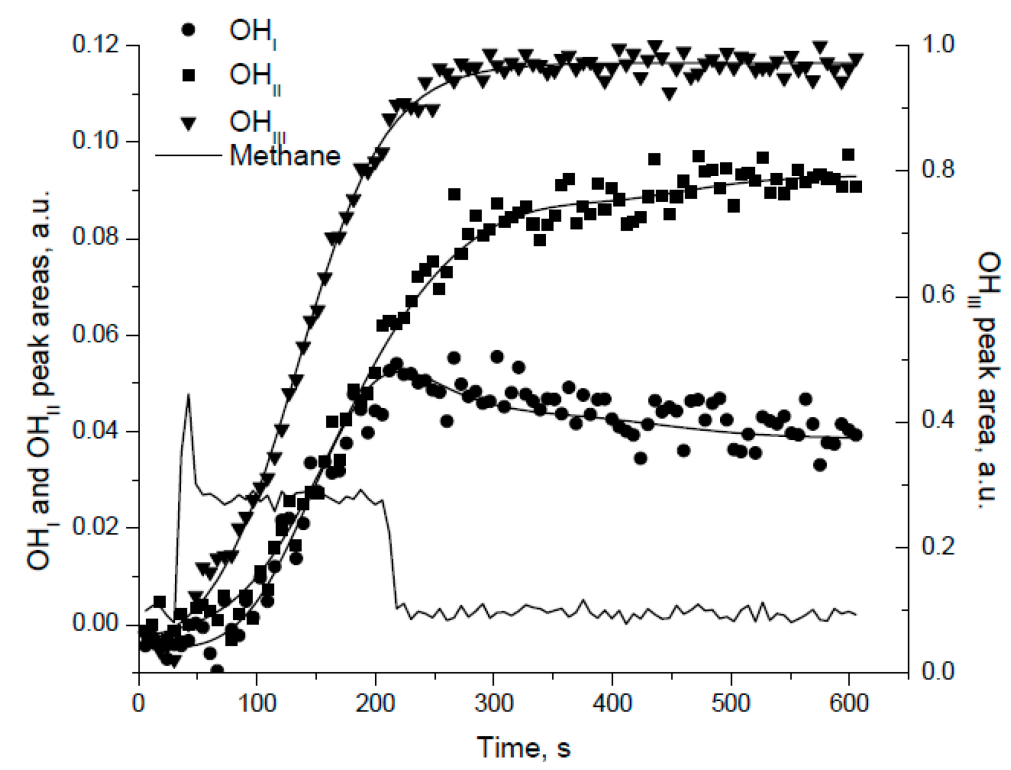

Figure 11. The normalized peak areas of different surface $\mathrm{OH}$ species generated during lean- $\mathrm{CH}_{4}-\mathrm{O}_{2}$ reaction at $175{ }^{\circ} \mathrm{C}$. Reproduced with permission from [30]. Copyright (C) 2004 Elsevier.

FTIR spectra measured during $\mathrm{CH}_{4}$ oxidation at $325{ }^{\circ} \mathrm{C}$ with $0.1 \% \mathrm{CH}_{4} / 4 \% \mathrm{O}_{2}$ in $\mathrm{He}$ over a series of 3 wt.\% $\mathrm{PdO}$ catalysts supported on $\mathrm{Al}_{2} \mathrm{O}_{3}, \mathrm{MgO}, \mathrm{TiO}_{2}$ and $\mathrm{MCM}-41$ [44] show that the hydroxyl coverage is dependent on the support. On $\mathrm{Al}_{2} \mathrm{O}_{3}$, well defined peaks similar to those identified by Ciuparu et al. [30] are observed, but no common peak among all catalysts that would provide evidence for $\mathrm{Pd}-\mathrm{OH}$ bond formation, are present. Furthermore the large contribution from $\mathrm{OH}$ bonding on the supports makes it impossible to directly identify the presence of $\mathrm{Pd}(\mathrm{OH})_{2}$ on these supports $[32,44]$. However, by using ${ }^{18} \mathrm{O}$ isotopic labeling and FTIR, the authors demonstrate that peaks associated with the accumulation of hydroxyls on $\mathrm{PdO}$ are not present at $325{ }^{\circ} \mathrm{C}$. Hence, the more recent evidence suggests that deactivation by $\mathrm{Pd}(\mathrm{OH})_{2}$ formation is unlikely, in agreement with the experimental observation that $\mathrm{Pd}(\mathrm{OH})_{2} / \mathrm{C}$ decomposes in $\mathrm{N}_{2}$ at about $250{ }^{\circ} \mathrm{C}$ [66]. In addition, evidence from temperature-programmed desorption studies of $\mathrm{H}_{2} \mathrm{O}$ adsorbed on $\mathrm{PdO}(101)$ thin films, suggests the formation of an $\mathrm{OH}-\mathrm{H}_{2} \mathrm{O}$ complex at low temperature $\left(<127{ }^{\circ} \mathrm{C}\right)$ and low coverage $(<1 / 2$ monolayer $)$, whereas $\mathrm{H}_{2} \mathrm{O}$ preferentially chemisorbs in molecular form at higher coverages [67].

Schwartz et al. [44] showed, however, that catalyst deactivation during $\mathrm{CH}_{4}$ oxidation correlates with hydroxyl accumulation on the oxide support. The redox mechanism for $\mathrm{CH}_{4}$ combustion on $\mathrm{Pd} / \mathrm{PdO}$ generally assumes dissociation of a $\mathrm{CH}_{4}$ molecule to yield a methyl fragment and a hydroxyl group $\left(\mathrm{CH}_{4}+\mathrm{Pd}-\mathrm{O}+\mathrm{Pd}-* \rightarrow \mathrm{Pd}-\mathrm{OH}+\mathrm{Pd}-\mathrm{CH}_{3}\right.$, where $\mathrm{Pd}-*$ represents a vacancy) $[68,69]$. H atoms are abstracted sequentially from the methyl group by neighboring Pd-O to form surface hydroxyl groups $(\mathrm{Pd}-\mathrm{OH})$. Recombination of surface hydroxyls yields water and a surface vacancy $\left(2 \mathrm{Pd}-\mathrm{OH} \rightarrow \mathrm{H}_{2} \mathrm{O}+\right.$ 
Pd-O + Pd-*), that is regenerated by oxygen $\left(2 \mathrm{Pd}-*+\mathrm{O}_{2} \rightarrow 2 \mathrm{Pd}-\mathrm{O}\right)[68,69]$. Based on their experimental studies, Schwartz et al. [44,57], proposed that during lean-burn $\mathrm{CH}_{4}$ oxidation, $\mathrm{O}_{2}$ molecules dissociate on Pd-* sites and exchange with oxygen on the support so that Pd active sites are re-oxidized with oxygen atoms from the support during the catalytic reaction as follows:

$$
\begin{gathered}
\mathrm{Pd}-\mathrm{O}+\mathrm{S}-* \leftrightarrow \mathrm{Pd}-*+\mathrm{S}-\mathrm{O} \\
\text { Pd-* }+ \text { S-O }{ }^{\mathrm{s}} \leftrightarrow \mathrm{Pd}-\mathrm{O}^{\mathrm{s}}+\mathrm{S}-*
\end{gathered}
$$

and overall:

$$
\mathrm{Pd}-\mathrm{O}+\mathrm{S}-\mathrm{O}^{\mathrm{s}} \leftrightarrow \mathrm{Pd}-\mathrm{O}^{\mathrm{s}}+\mathrm{S}-\mathrm{O}
$$

where $\mathrm{S}$ represents the support, $\mathrm{S}-*$ is an $\mathrm{O}$ vacancy on the support and $\mathrm{O}^{\mathrm{s}}$ represents an $\mathrm{O}$ atom associated with the solid oxide. This proposed mechanism suggests the possibility that a primary cause for catalyst deactivation is hydroxyl accumulation on the support, which hinders oxygen migration and exchange processes.

Evidence for $\mathrm{O}$ exchange with the support is provided by the isotopic labeling experiments summarized in Figure 12, during which $\mathrm{Pd}^{18} \mathrm{O} / \mathrm{Al}_{2}{ }^{16} \mathrm{O}_{3}$ and $\mathrm{Pd}^{18} \mathrm{O} / \mathrm{Mg}^{16} \mathrm{O}$ were exposed to ${ }^{18} \mathrm{O}_{2} / \mathrm{He}$ flow at $400{ }^{\circ} \mathrm{C}$ [57]. An increase in ${ }^{16} \mathrm{O}^{18} \mathrm{O}$ signal intensity with time is proposed to arise from oxygen exchange with the catalyst support [44]. The ${ }^{16} \mathrm{O}^{18} \mathrm{O}$ signal (see lower, separate dashed line in Figure 12) is reduced when $\mathrm{H}_{2}{ }^{16} \mathrm{O}$ is injected to the feed and is recovered when $\mathrm{H}_{2}{ }^{16} \mathrm{O}$ is removed. Apparently, hydroxyl groups tend to migrate to the oxide support rather than desorb. By increasing the concentration of hydroxyl groups, through addition and dissociation of $\mathrm{H}_{2} \mathrm{O}$, oxygen exchange of $\mathrm{Pd}$-* active sites with the oxide support $\left(\mathrm{S}-\mathrm{O}^{\mathrm{s}}\right)$ is interrupted. Thus, the number of $\mathrm{PdO}$ sites participating in the $\mathrm{CH}_{4}$ oxidation reaction decreases with time, as $\mathrm{H}_{2} \mathrm{O}$ dissociates and $\mathrm{OH}$ coverage of the support increases, with a consequent decrease in $\mathrm{CH}_{4}$ conversion [44]. This proposed mechanism of catalyst deactivation is believed to occur at temperatures below $450{ }^{\circ} \mathrm{C}$. Finally, the authors note that the rate of deactivation on $\mathrm{Pd} / \mathrm{Al}_{2} \mathrm{O}_{3}$ catalysts, with higher concentrations of hydroxyl during reaction, is higher than on catalysts containing a support with higher oxygen mobility $(\mathrm{Pd} / \mathrm{MgO})[44,57]$.

Ciuparu et al. [70] also reported on pulsed experiments with ${ }^{18} \mathrm{O}_{2}$ over pure $\mathrm{Pd}$ and $\mathrm{Pd} / \mathrm{ZrO} 2$ catalysts, oxidized before reaction, to clarify the effect of hydroxyls on the surface oxygen exchange. They determined that due to the slow recombination of hydroxyls and hence $\mathrm{H}_{2} \mathrm{O}$ desorption from the $\mathrm{Pd}$ catalyst surface during $\mathrm{CH}_{4}$ oxidation $\left(2 \mathrm{Pd}-\mathrm{OH} \rightarrow \mathrm{H}_{2} \mathrm{O}+\mathrm{Pd}-\mathrm{O}+\mathrm{Pd}-*\right)$, the isotopic exchange of oxygen with the $\mathrm{Pd}$ sites (see Figure 13) occurs before $\mathrm{H}_{2} \mathrm{O}$ desorption from the surface. The oxygen vacancies on the $\mathrm{PdO}$ surface resulting from $\mathrm{H}_{2} \mathrm{O}$ desorption are thus rapidly filled by oxygen from the $\mathrm{PdO}$ bulk or oxide support $\left(\mathrm{Pd}-*+\mathrm{S}-\mathrm{O}^{\mathrm{s}} \leftrightarrow \mathrm{Pd}-\mathrm{O}^{\mathrm{s}}+\mathrm{S}-*\right)$. In fact, in this unsteady-state experiment, the labeled oxygen pulsed through the catalyst bed, is purged from the reactor before $\mathrm{H}_{2} \mathrm{O}$ is desorbed [70]. These observations are in agreement with the studies of Schwartz et al. [44,57] already discussed and confirm that the accumulation of hydroxyls on the Pd catalyst surface impedes the oxygen exchange and limits Pd catalyst activity. 


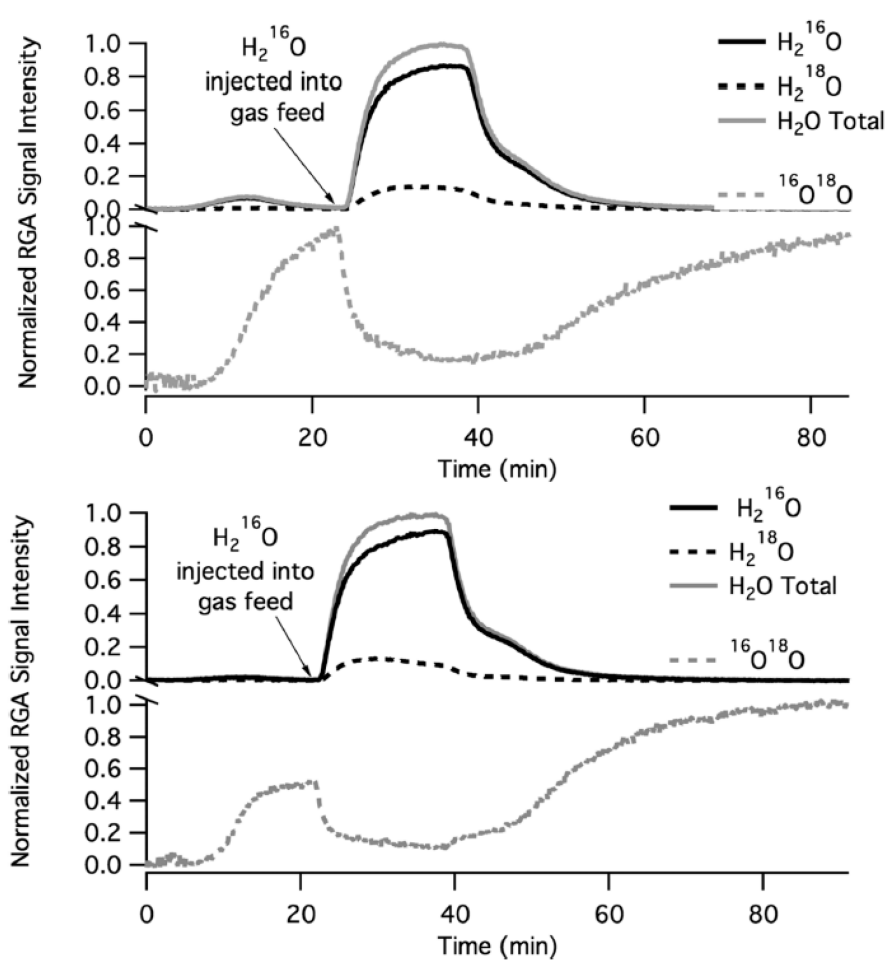

Figure 12. Oxygen exchange of (a) 3 wt.\% $\mathrm{Pd}^{18} \mathrm{O} / \mathrm{Al}_{2}{ }^{16} \mathrm{O}_{3}$ (top) and (b) 3 wt.\% $\mathrm{Pd}^{18} \mathrm{O} / \mathrm{Mg}^{16} \mathrm{O}$ (bottom) with catalyst supports in a flow of ${ }^{18} \mathrm{O}_{2} / \mathrm{He}$ at $400{ }^{\circ} \mathrm{C} . \mathrm{H}_{2}{ }^{16} \mathrm{O}$ was injected at some time to probe its effect on oxygen exchange. Reproduced with permission from [44]. Copyright (C2012 American Chemical Society.
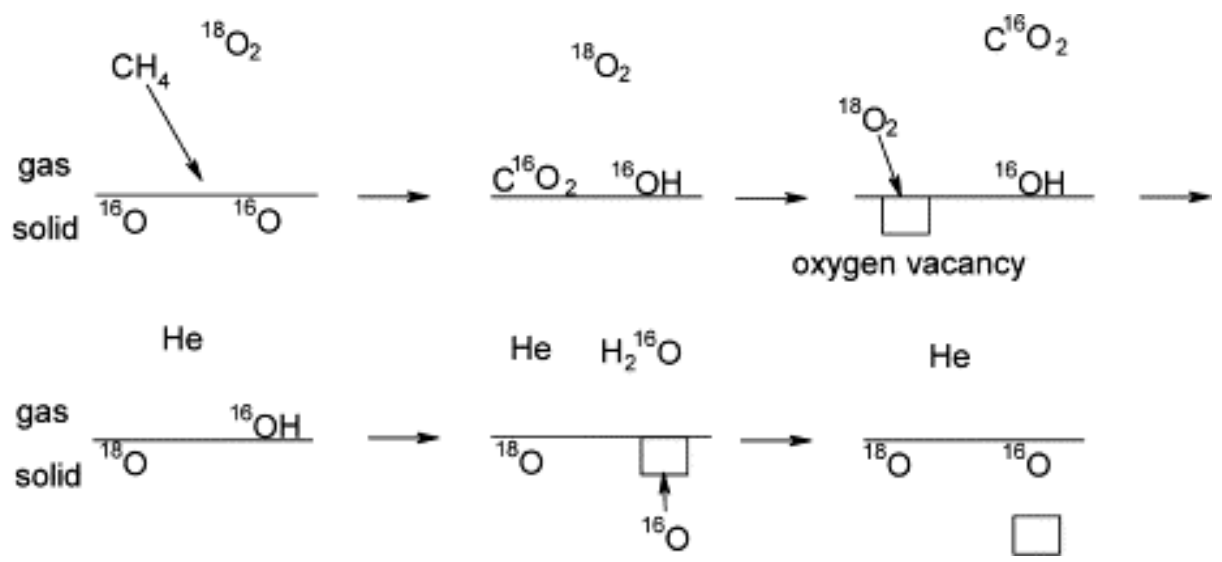

Figure 13. Schematic of oxygen exchange during $\mathrm{CH}_{4}$ oxidation using labeled pulsed experiments. Reproduced with permission from [70]. Copyright (C) 2002 Elsevier.

\section{The Use of Pd-Bimetallic Catalysts for $\mathrm{CH}_{4}$ Oxidation}

Pd-bimetallic catalysts have been studied to improve stability of Pd catalysts for $\mathrm{CH}_{4}$ oxidation [19,51,71,72]. Pd-bimetallic catalysts are usually less active than Pd alone [64,73-75] simply because they contain less $\mathrm{Pd}$, the most active metal for $\mathrm{CH}_{4}$ oxidation [20,25]. The lower activity of the bimetallic compared to $\mathrm{Pd}$ alone may also be due to the presence of smaller amounts of $\mathrm{PdO}$ as a result of alloy formation between Pd and Pt [64], or the transformation of PdO to Pd metal [76]. According 
to Ozawa et al. [77] the addition of $\mathrm{Pt}$ improves $\mathrm{PdO} / \mathrm{Al}_{2} \mathrm{O}_{3}$ catalyst stability by preventing the growth of $\mathrm{PdO}$ and $\mathrm{Pd}-\mathrm{Pt}$ particles during $\mathrm{CH}_{4}$ oxidation at high temperature $\left(800{ }^{\circ} \mathrm{C}\right)$ [77].

Several studies have reported higher initial activity of Pd-bimetallic catalysts compared to $\mathrm{Pd}$ alone $[17,19,51,78]$. These researchers suggest that the second metal added to $\mathrm{Pd}$ dissociates $\mathrm{O}_{2}$ and the resulting $\mathrm{O}$ atoms are adsorbed by $\mathrm{Pd}$, helping to maintain $\mathrm{PdO}$ active sites. Ishihara et al. [78] reported a $T_{50}$ of $533{ }^{\circ} \mathrm{C}$ for a 1 wt. $\% \mathrm{Pd} / \mathrm{Al}_{2} \mathrm{O}_{3}$ catalyst, whereas for a $\mathrm{Pd}-\mathrm{Ni} / \mathrm{Al}_{2} \mathrm{O}_{3}$ catalyst $(\mathrm{Pd}: \mathrm{Ni}=9: 1) T_{50}$ was $380{ }^{\circ} \mathrm{C}$. In another study, it was reported that a higher dispersion of $\mathrm{PdO}$ on $\mathrm{PdO}-\mathrm{Pt} / \alpha-\mathrm{Al}_{2} \mathrm{O}_{3}$ catalyst $(27 \%)$ compared to $\mathrm{PdO} / \alpha-\mathrm{Al}_{2} \mathrm{O}_{3}(14 \%)$ results in higher initial activity and higher stability of the bimetallic catalyst [51] . After exposing the $\mathrm{PdO} / \alpha-\mathrm{Al}_{2} \mathrm{O}_{3}$ catalyst to the reaction feed stream for $6 \mathrm{~h}$ at $350{ }^{\circ} \mathrm{C}$, an increase in average particle size from 8 to $11 \mathrm{~nm}$ is observed, whereas the average particle size does not change significantly for the $\mathrm{PdO}-\mathrm{Pt} / \alpha-\mathrm{Al}_{2} \mathrm{O}_{3}$ catalyst [51].

Persson et al. [73] examined a series of Pd-bimetallics supported on $\mathrm{Al}_{2} \mathrm{O}_{3}$ finding that the metallic phase structure has a significant influence on the catalyst stability. For example, in several bimetallic systems (PdAg, $\mathrm{PdCu}, \mathrm{PdRh}$, and PdIr) separate phases of each metal oxide are formed after calcination (at $1000{ }^{\circ} \mathrm{C}$ for $1 \mathrm{~h}$ followed by $1000{ }^{\circ} \mathrm{C}$ for $2 \mathrm{~h}$ after loading the supported metal oxide powders onto a cordierite monolith) and this enhances catalyst stability in the case of the $\mathrm{PdCu}$ and PdAg (as measured stepwise at temperatures from $400-800{ }^{\circ} \mathrm{C}$ in $1.4 \% \mathrm{CH}_{4}$ in dry air at a space velocity of 250,000 $\mathrm{h}^{-1}$ ). Formation of a Co or Ni aluminate spinel in PdCo and PdNi bimetallics, however, does not improve catalyst stability, whereas alloy formation in $\mathrm{PdPt}$ and $\mathrm{PdAu}$ on $\mathrm{Al}_{2} \mathrm{O}_{3}$ increases hydrothermal stability in the presence of $15 \% \mathrm{H}_{2} \mathrm{O} /$ air at $1000{ }^{\circ} \mathrm{C}$ for $10 \mathrm{~h}$. In another study by Persson et al. [64], Pd-Pt bimetallic catalysts on various supports (alumina, zirconia) were shown to have higher thermal stability than monometallic $\mathrm{Pd}$ during $\mathrm{CH}_{4}$ oxidation in dry air $\left(1.5 \% \mathrm{CH}_{4}\right.$ in air at a GHSV $250,000 \mathrm{~h}^{-1}$ ). The stability of the Pd-Pt catalysts improved at lower temperatures (up to $620{ }^{\circ} \mathrm{C}$ ). At temperatures of $520{ }^{\circ} \mathrm{C}$ and $570{ }^{\circ} \mathrm{C} \mathrm{CH}_{4}$ conversion on $\mathrm{Pd}$-Pt catalysts increased with time-on-stream. Above $620^{\circ} \mathrm{C}$ (especially at $670{ }^{\circ} \mathrm{C}$ and $720{ }^{\circ} \mathrm{C}$ ) conversion decreased with time-onstream. Those catalysts with higher initial activity also had higher deactivation rates. The deactivation cannot be attributed to $\mathrm{PdO}$ decomposition because the initial activity test showed that PdO decomposition started at higher temperature $\left(770{ }^{\circ} \mathrm{C}\right.$ with 1.5 vol. $\% \mathrm{CH}_{4}$ in air). According to XRD results, no $\mathrm{PdO}$ decomposition was observed at temperatures below $800{ }^{\circ} \mathrm{C}$ for the $\mathrm{Pd} / \mathrm{Al}_{2} \mathrm{O}_{3}$, although $\mathrm{PdO}$ decomposition at $\sim 700{ }^{\circ} \mathrm{C}$ may have yielded $\mathrm{Pd}$ that was not detectable by XRD (due to low concentration or high dispersion).

The amount of second metal added to the Pd can also affect the stability of the bimetallic catalyst. Persson et al. [74] reported that Pd-Pt bimetallic catalysts with Pd:Pt ratios of 2:1 and 1:1 are stable. Time-on-stream $\mathrm{CH}_{4}$ oxidation experiments (in $1.5 \% \mathrm{CH}_{4}$ in air at a space velocity of $250,000 \mathrm{~h}^{-1}$ ) for both a 5 wt. $\% \mathrm{Pd} / \mathrm{Al}_{2} \mathrm{O}_{3}$ and a 2:1 $\mathrm{Pd}: \mathrm{Pt} / \mathrm{Al}_{2} \mathrm{O}_{3}$ bimetallic with total metal loading of 5 wt.\% were studied over a wide range of temperatures $\left(470-720{ }^{\circ} \mathrm{C}\right)$ [64]. The temperature was increased from $470{ }^{\circ} \mathrm{C}$ to $720^{\circ} \mathrm{C}$ stepwise by $50{ }^{\circ} \mathrm{C}$ and held for $1 \mathrm{~h}$ at each temperature. $\mathrm{CH}_{4}$ conversion over the $\mathrm{Pd} / \mathrm{Al}_{2} \mathrm{O}_{3}$ and $\mathrm{Pd}-\mathrm{Pt} / \mathrm{Al}_{2} \mathrm{O}_{3}$ catalyst decreased during the $1 \mathrm{~h}$ reaction time at each temperature. However, the decrease in conversion was lower for the bimetallic catalyst compared to the Pd catalyst. The decrease in activity was higher at higher temperatures $\left(670{ }^{\circ} \mathrm{C}\right.$ and $\left.720{ }^{\circ} \mathrm{C}\right)$, especially for the $\mathrm{Pd}$ catalyst. In situ XRD spectra of the Pd-Pt bimetallic catalysts are shown in Figure 14. At room temperature, a sharp peak corresponding to Pd-Pt (111) and a small peak corresponding to PdO (101) are observed for 
the PdPt- $\mathrm{Al}_{2} \mathrm{O}_{3}$ catalyst. By increasing the temperature to $300{ }^{\circ} \mathrm{C}$, the $\mathrm{PdO}$ peak disappears and then reappears at $500{ }^{\circ} \mathrm{C}$. The $\mathrm{Pd}-\mathrm{Pt}$ peak intensity reaches a maximum at $700{ }^{\circ} \mathrm{C}$ while the $\mathrm{PdO}$ peak disappears at this temperature. The formation of $\mathrm{Pd}-\mathrm{Pt}$ instead of $\mathrm{PdO}$ is consistent with deactivation of the bimetallic catalyst at high temperature $\left(700{ }^{\circ} \mathrm{C}\right)$.

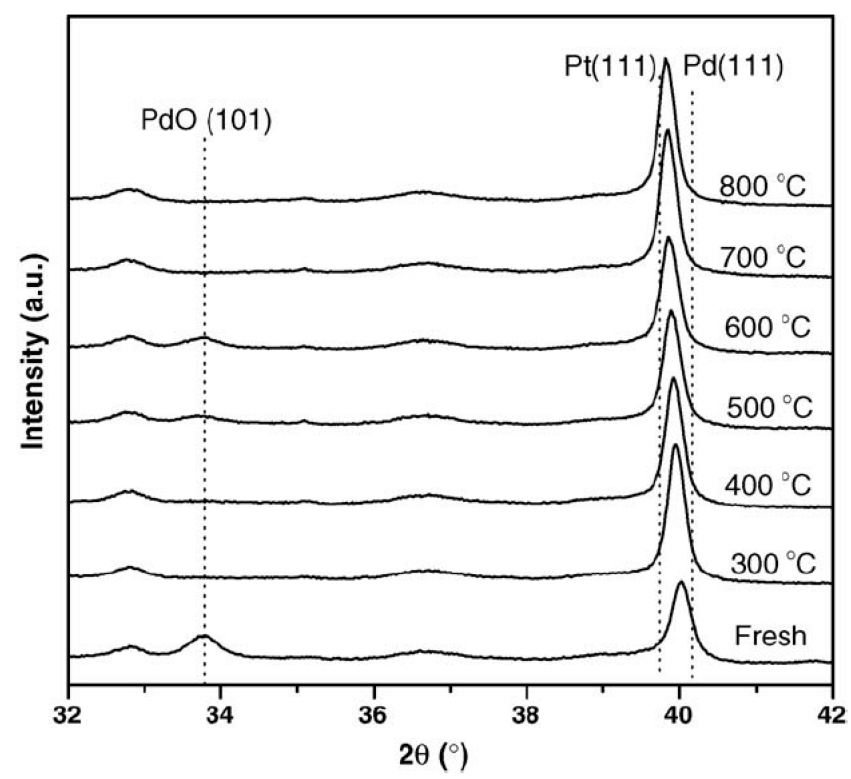

Figure 14. High-temperature in situ XRD profiles of $\mathrm{PdPt}-\mathrm{Al}_{2} \mathrm{O}_{3}$ during heating. Reprinted with permission from [64]. Copyright (C) 2006 Elsevier.

Steady-state experiments using a 18.7 wt.\% $\mathrm{Pd} / \mathrm{Al}_{2} \mathrm{O}_{3}$ catalyst with different loadings of $\mathrm{Pt}$ (1.6, 3.1 and 3.9 wt.\%) (Figure 15) reported by Ozawa et al. [77], also provide some insight into the improved stability of bimetallic catalysts as Pt content increases. In this study, reaction temperature was held at $800{ }^{\circ} \mathrm{C}$ and $\mathrm{CH}_{4}$ combustion rate was measured over a $10 \mathrm{~h}$ period using a $1 \% \mathrm{CH}_{4}$ in air feed gas at a GHSV of $1,500,000 \mathrm{~mL} /\left(\mathrm{g}_{\mathrm{cat}} \mathrm{h}\right)$. Deactivation rate is shown to decrease as the Pt loading of the Pd-Pt bimetallics increases. For example, the combustion rate for the 18 wt.\% Pd-3.9 wt.\% Pt/Al $\mathrm{Al}_{2} \mathrm{O}_{3}$ decreases from $710 \mu \mathrm{mol} \mathrm{s} \mathrm{g}^{-1}$ to $460 \mu \mathrm{mol} \mathrm{s} \mathrm{g}^{-1}$ after $10 \mathrm{~h}$, whereas it decreases to $400 \mu \mathrm{mol} \mathrm{s} \mathrm{g}^{-1} \mathrm{~g}^{-1}$ for the 18.4 wt.\% Pd-1.6 wt.\% $\mathrm{Pt} / \mathrm{Al}_{2} \mathrm{O}_{3}$ catalyst.

XRD analysis of the catalysts studied by Ozawa et al. [77] after $10 \mathrm{~h}$ reaction indicates $\mathrm{PdO}$ to be present in the Pt-doped catalysts while no $\mathrm{Pd}^{0}$ is observed. However, $\mathrm{Pd}^{0}$ is present in the $\mathrm{Pd}$ monometallic catalyst, likely because of the decomposition of $\mathrm{PdO}$ at the high temperature of the reaction $\left(800^{\circ} \mathrm{C}\right)$. In addition, the crystallite size of the $\mathrm{PdO}(101)$ in the Pd catalyst is larger than for the Pd-Pt catalysts. Table 4 compares changes in PdO particle size and BET surface area before and after $10 \mathrm{~h}$ reaction for the same $\mathrm{Pd}$ and Pd-Pt catalysts. From these data it is clear that the extent of sintering of the Pd catalyst is greater than for the Pd-Pt catalysts. The time-on-stream conversion data reported by Ozawa et al. [77] (Figure 15) were fitted to a deactivation equation with two terms, the first representing rapid transformation of $\mathrm{PdO}$ to $\mathrm{Pd}^{0}$ of the $\mathrm{Pd}-\mathrm{Pt}$ alloy phase, and the second associated with the slow growth of the PdO crystallite [77]. The deactivation is affected more by the second term suggesting that particle growth of the $\mathrm{PdO}$ is the main cause of catalyst deactivation at the chosen reaction conditions [77]. 


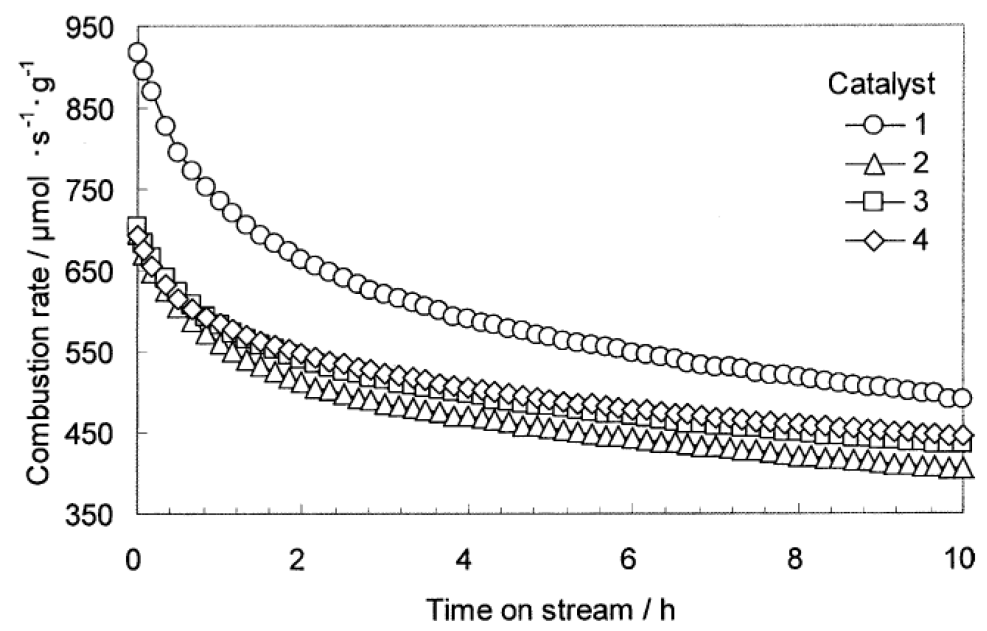

Figure 15. $\mathrm{CH}_{4}$ combustion rate at $800{ }^{\circ} \mathrm{C}$ with time on stream. Combustion conditions:

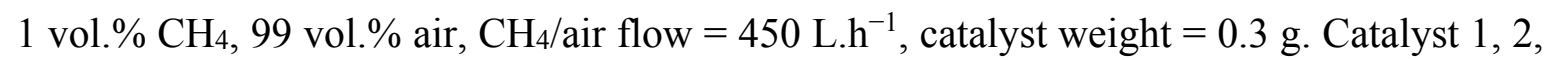
3, and 4 represent 18.7 wt.\% Pd, 18.4 wt.\% Pd-1.6 wt.\% Pt, 18.1 wt.\% Pd-3.4 wt.\% Pt, and 18.0 wt.\% Pd-3.9 wt.\% Pt over $\mathrm{Al}_{2} \mathrm{O}_{3}$ catalysts. Reprinted with permission from [77]. Copyright (C) 2004 Elsevier.

Table 4. Changes in $\mathrm{Pd}$ and $\mathrm{Pt}-\mathrm{Pd}$ catalyst properties before and after aging. Adapted from [77].

Catalyst, wt.\% on $\mathrm{Al}_{2} \mathrm{O}_{3}$

$18.7 \%$ Pd

$18.4 \%$ Pd-1.6\% Pt

$18.1 \%$ Pd-3.1\% Pt

$18.0 \%$ Pd-3.9\% Pt

\begin{tabular}{cccccc}
\hline \multirow{2}{*}{ BET area, $\mathrm{m}^{2} / \mathrm{g}$} & Fresh & 56 & 51 & 51 & 46 \\
& Aged & 46 & 46 & 46 & 52 \\
\hline \multirow{2}{*}{ PdO size, $\mathrm{nm}$} & Fresh & 12.5 & 15.3 & 15.2 & 14.7 \\
& Aged & 17.9 & 18.0 & 16.7 & 16.2 \\
\hline
\end{tabular}

These results are in a good agreement with the results reported by Yamamoto et al. [72] in which a Pd-Pt bimetallic catalyst was more active for $\mathrm{CH}_{4}$ conversion than $\mathrm{Pd}$ (as measured by the temperature required for $50 \% \mathrm{CH}_{4}$ conversion) and the conversion was maintained following $2500 \mathrm{~h}$ time-on-stream at $385{ }^{\circ} \mathrm{C}$. XRD analyses showed that the crystallite growth as a function of time for both $\mathrm{Pd}(111)$ and $\mathrm{PdO}$ (101) was faster on the $\mathrm{Pd}(10 \mathrm{~g} / \mathrm{L}) / \mathrm{Al}_{2} \mathrm{O}_{3}$ catalyst than the $\mathrm{Pd}(10 \mathrm{~g} / \mathrm{L})-\mathrm{Pt}(10 \mathrm{~g} / \mathrm{L}) / \mathrm{Al}_{2} \mathrm{O}_{3}$ catalyst. Hence one concludes that the presence of $\mathrm{Pt}$ retards the sintering of $\mathrm{PdO}$.

Effects of $\mathrm{H}_{2} \mathrm{O}$ on deactivation of $\mathrm{Pt}$ versus $\mathrm{Pt}-\mathrm{Pd}$ catalysts have also been reported, at both thermal and hydrothermal aging conditions [17,19,71]. Pieck et al. [17] reported that the $T_{50}$ of a $0.4 \%$ Pt- $0.8 \%$ $\mathrm{Pd} / \mathrm{Al}_{2} \mathrm{O}_{3}$ catalyst after thermal treatment at $600{ }^{\circ} \mathrm{C}$ for $4 \mathrm{~h}$ in wet air $\left(60 \mathrm{~cm}^{3} \mathrm{~min}^{-1}\right.$ air flow with $0.356 \mathrm{~cm}^{3} \mathrm{~h}^{-1}$ water ), is $\sim 50{ }^{\circ} \mathrm{C}$ lower than that obtained over a Pd catalyst. Lapisardi et al. [19] reported that a fresh $\mathrm{Pd}_{0.93}-\mathrm{Pt}_{0.07} / \mathrm{Al}_{2} \mathrm{O}_{3}$ catalyst (total metal loading 2.12 wt.\% with $\mathrm{Pd}: \mathrm{Pt}$ molar ratio of 0.93:0.07) is as active as a fresh $\mathrm{Pd} / \mathrm{Al}_{2} \mathrm{O}_{3}$ catalyst in a dry feed [19]. Interestingly, the $\mathrm{Pd} 0.93-\mathrm{Pt}_{0.07} / \mathrm{Al}_{2} \mathrm{O}_{3}$ catalyst is less affected by addition of 10 vol.\% steam to the feed stream than the 2.2 wt. $\% ~ \mathrm{Pd} / \mathrm{Al}_{2} \mathrm{O}_{3}$ catalyst. The $T_{50}$ for the Pd-Pt bimetallic increases from $320{ }^{\circ} \mathrm{C}$ to $400{ }^{\circ} \mathrm{C}$ when 10 vol.\% steam is added to the feed stream, whereas the corresponding increase in $\mathrm{T}_{50}$ for the $\mathrm{Pd} / \mathrm{Al}_{2} \mathrm{O}_{3}$ 
catalyst is from $320{ }^{\circ} \mathrm{C}$ to $425{ }^{\circ} \mathrm{C}$. Thus, the Pd-Pt bimetallic, containing only $0.26 \mathrm{wt} \% \mathrm{Pt}$ is more active and stable than the $\mathrm{Pd}$ catalyst for $\mathrm{CH}_{4}$ oxidation in the presence of steam.

The stabilities of Pt and Pt-Pd catalysts each loaded on a wash coated monolith have also been reported [71]. A feed stream with 4067 ppmv $\mathrm{CH}_{4}$ in air was reacted over these catalysts as reaction temperature increased from 300 to $700{ }^{\circ} \mathrm{C}$ stepwise in $50{ }^{\circ} \mathrm{C}$ increments. $\mathrm{CH}_{4}$ conversion was monitored for a period of $1 \mathrm{~h}$ at each temperature. Subsequently the temperature was decreased to $300^{\circ} \mathrm{C}$ also in 50 ${ }^{\circ} \mathrm{C}$ steps, again holding at each temperature for $1 \mathrm{~h}$. The conversion of $\mathrm{CH}_{4}$ was compared for both heating and cooling cycles. The results show that the Pt-Pd catalyst is more active than the Pt catalyst. The comparison between the heating and cooling cycles was also done for steam-aged catalysts, in which the catalysts were exposed to the feed stream at $650{ }^{\circ} \mathrm{C}$ with 5 vol.\% water for $20 \mathrm{~h}$. Table 5 lists the $T_{50}$ for both fresh Pt and Pd-Pt catalysts, the steam-aged catalysts during tests in a dry feed and the steam-aged catalysts tested in a wet feed, containing $5 \mathrm{wt} \% \mathrm{H}_{2} \mathrm{O}$. The data show that the fresh PdPt catalyst is more active than the fresh Pt catalyst. Higher activities are also observed for steam-aged Pd-Pt catalysts tested in dry or wet feed gas.

Table 5. $T_{50}$ for fresh and steam aged Pd and Pt-Pd catalysts operated in dry and wet feed. Combustion conditions: 4067 vol. ppm $\mathrm{CH}_{4}$; total flow rate of $234.5 \mathrm{~cm}^{3} / \mathrm{min} ; 500 \mathrm{mg}$ catalyst; 5 vol.\% water in wet feed. Adapted from [71].

\begin{tabular}{cccc}
\hline \multirow{2}{*}{ Catalyst } & \multicolumn{3}{c}{ Temperature at 50\% $\mathbf{C H}_{4}$ conversion $\left(\boldsymbol{T}_{\mathbf{5 0}}\right),{ }^{\circ} \mathrm{C}$} \\
\cline { 2 - 4 } & Fresh & Steam-aged & Steam-aged \\
& Dry feed & Dry feed & Wet feed \\
\hline Pt & 540 & 610 & 610 \\
$4: 1 \mathrm{Pt}-\mathrm{Pd}$ & 400 & 470 & 535 \\
\hline
\end{tabular}

\section{Kinetic Consequences of $\mathrm{H}_{2} \mathrm{O}$ on $\mathrm{CH}_{4}$ Oxidation over Pd Catalysts}

The rate of $\mathrm{CH}_{4}$ oxidation over Pd catalysts is influenced by temperature, reactant partial pressures, the state of the $\mathrm{Pd}$ at reaction conditions ( $\mathrm{Pd}^{0}, \mathrm{PdO}$ or a sub-oxide), possibly $\mathrm{Pd}$ crystallite size (i.e., may be structure-sensitive), and inhibition by products $\mathrm{H}_{2} \mathrm{O}$ and $\mathrm{CO}_{2}$. Consequently, kinetic parameters reported in the literature vary over wide ranges; this is especially true of the apparent activation energy for $\mathrm{CH}_{4}$ oxidation [20]. As noted by Carstens et al. [79], rate data must account for the inhibition effect of $\mathrm{H}_{2} \mathrm{O}$ when determining the activation barrier, but Ciuparu et al. [43] has shown that the correction is complicated by the fact that the effect of $\mathrm{H}_{2} \mathrm{O}$ inhibition is temperature dependent. For example, the apparent activation energy for $\mathrm{CH}_{4}$ oxidation over a $\mathrm{Pd} / \mathrm{ZrO} 2$ catalyst is estimated to be $180 \mathrm{~kJ} / \mathrm{mol}$ from data measured at temperatures below $192{ }^{\circ} \mathrm{C}$, whereas a value of $87 \mathrm{~kJ} / \mathrm{mol}$ is obtained at temperatures above $192{ }^{\circ} \mathrm{C}$ [42]. The higher value of the apparent activation energy at lower temperatures is attributed to the strong inhibiting effect of $\mathrm{H}_{2} \mathrm{O}$ on the Pd catalyst.

Zhu et al. [80] reported kinetic parameters for $\mathrm{CH}_{4}$ oxidation over a series of model $\mathrm{Pd}$ and $\mathrm{PdO}$ surfaces and foils, and compared the values to literature data on supported Pd catalysts (Table 6). From Table 6 the reaction orders for $\mathrm{CH}_{4}$ and $\mathrm{O}_{2}$ are probably not sensitive to the structure of the Pd catalyst, 
although on the supported catalysts the reaction orders for $\mathrm{H}_{2} \mathrm{O}$ vary from -0.25 to -1.3 . Taking account of the error in the $E_{\mathrm{a}}$ estimates $( \pm 20 \mathrm{~kJ} / \mathrm{mol})$, Zhu et al. [80] concluded that on the large single-crystal model catalysts, the activation energies are similar and the combustion of $\mathrm{CH}_{4}$ over $\mathrm{Pd}$ or $\mathrm{PdO}$ is not sensitive to the structure of the catalyst. Larger $E_{\mathrm{a}}$ values are reported for the $\mathrm{Pd}$ /oxide-supports (150-185 kJ/mol) corrected for the effect of $\mathrm{H}_{2} \mathrm{O}$ (assuming an order of -1) [79], whereas the much smaller $\mathrm{E}_{\mathrm{a}}$ for the $\mathrm{Pd} /$ zeolite catalysts $(72-77 \mathrm{~kJ} / \mathrm{mol})$ are possibly associated with the high acidity and high $\mathrm{OH}$ surface concentration of zeolites, in obvious contrast to the observed inhibition by $\mathrm{OH}$ groups for $\mathrm{PdO}$ supported on conventional supports. The negative orders of reaction for $\mathrm{H}_{2} \mathrm{O}$ are indicative of the varying degrees of inhibition of $\mathrm{CH}_{4}$ oxidation by $\mathrm{H}_{2} \mathrm{O}$ on $\mathrm{Pd}$ and $\mathrm{PdO}$ surfaces and catalysts.

Table 6. Kinetic parameters for $\mathrm{CH}_{4}$ oxidation over Pd catalysts.

\begin{tabular}{|c|c|c|c|c|c|c|}
\hline \multirow{2}{*}{ Catalyst } & \multirow{2}{*}{$\begin{array}{c}E_{\mathrm{a}} \\
\mathrm{kJ} / \mathrm{mol}\end{array}$} & \multicolumn{3}{|c|}{ Reaction order } & \multirow{2}{*}{$\begin{array}{c}T \text { Range } \\
{ }^{\circ} \mathrm{C}\end{array}$} & \multirow{2}{*}{ Refs } \\
\hline & & $\mathrm{CH}_{4}$ & $\mathbf{O}_{2}$ & $\mathrm{H}_{2} \mathrm{O}$ & & \\
\hline \multicolumn{7}{|l|}{ Model Catalysts } \\
\hline Pd foil & 125 & 0.7 & -0.1 & 0.05 & $296-360$ & [81] \\
\hline $\operatorname{Pd}(111)$ & 140 & 0.7 & -0.1 & 0.05 & $296-360$ & {$[80]$} \\
\hline $\operatorname{Pd}(100)$ & 130 & 0.9 & 0.01 & 0.07 & $296-360$ & {$[80]$} \\
\hline $\mathrm{PdO}$ foil & 125 & 0.7 & 0.2 & -0.9 & $296-360$ & {$[80]$} \\
\hline $\mathrm{PdO}(111)$ & 140 & 0.8 & -0.1 & -0.9 & $296-360$ & {$[80]$} \\
\hline $\operatorname{PdO}(100)$ & 125 & 0.8 & 0.1 & -1.0 & $296-360$ & {$[80]$} \\
\hline \multicolumn{7}{|l|}{ Supported Catalysts } \\
\hline Pd black & 135 & 0.7 & 0.1 & -0.8 & $296-360$ & [81] \\
\hline $8.5 \% \mathrm{Pd} / \mathrm{Al}_{2} \mathrm{O}_{3}$ & 150 & 1 & 0 & -1 & $232-360$ & {$[80,82]$} \\
\hline $0.5 \% \mathrm{Pd} / \mathrm{Al}_{2} \mathrm{O}_{3}{ }^{\mathrm{a}}$ & 60 & 0.90 & 0.08 & -1.3 to -0.9 & $240-400$ & {$[83]$} \\
\hline $10 \% \mathrm{Pd} / \mathrm{ZrO}_{2}$ & 185 & 1 & 0 & -1 & $232-360$ & {$[80,82]$} \\
\hline $5 \% \mathrm{Pd} / \mathrm{ZrO}_{2}$ & 185 & 1.1 & 0.1 & -1.0 & $250-280$ & {$[68]$} \\
\hline $1 \% \mathrm{Pd} / \mathrm{ZrO}_{2}$ & 172 & 1 & 0 & -1.0 & $227-441$ & {$[53]$} \\
\hline $1 \% \mathrm{Pd} / \mathrm{SiO}_{2}$ & - & 1 & 0 & -0.25 & $227-441$ & {$[53]$} \\
\hline $2.8 \% \mathrm{Pd} / \mathrm{H}-\mathrm{Mord}$ & 77 & 0.7 & -0.1 & -0.4 & $342-417$ & {$[33]$} \\
\hline 2.5\% Pd-H-beta & 72 & 0.5 & 0.2 & -0.5 & $342-417$ & {$[33]$} \\
\hline
\end{tabular}

${ }^{\text {a }} E_{\mathrm{a}}$ determined under dry reaction conditions, correction for $\mathrm{H}_{2} \mathrm{O}$ inhibition. 
The role of $\mathrm{H}_{2} \mathrm{O}$ in the inhibition of $\mathrm{PdO}$ catalysts during $\mathrm{CH}_{4}$ oxidation has been documented in this review to relate to the adsorption and slow desorption of $\mathrm{H}_{2} \mathrm{O}$ on active sites during reaction. Kikuchi et al. [16] proposed a kinetic model assuming competitive adsorption between $\mathrm{H}_{2} \mathrm{O}$ and $\mathrm{CH}_{4}$ on $\mathrm{PdO}$ sites, where dissociative $\mathrm{CH}_{4}$ adsorption was assumed to be the rate determining step (RDS) and the coverage by $\mathrm{C}$-species was assumed to be negligible. The main elementary steps of the reaction are postulated as follows:

$$
\begin{gathered}
\mathrm{H}_{2} \mathrm{O}_{(\mathrm{g})}+\mathrm{s} \rightarrow \mathrm{H}_{2} \mathrm{O}-\mathrm{s} \\
\mathrm{CH}_{4(\mathrm{~g})}+2 \mathrm{~s} \rightarrow \mathrm{CH}_{3}-\mathrm{s}+\mathrm{H}-\mathrm{s}
\end{gathered}
$$

from which the following rate expression is derived [16]:

$$
r=k_{r} \frac{P_{\mathrm{CH}_{4}}}{1+K_{\mathrm{H}_{2} \mathrm{O}} P_{\mathrm{H}_{2} \mathrm{O}}}
$$

where $r$ is the reaction rate, $\mathrm{k}_{\mathrm{r}}$ is the rate constant for $\mathrm{H}$ abstraction, $\mathrm{K}_{\mathrm{H}_{2} \mathrm{O}}$ is the $\mathrm{H}_{2} \mathrm{O}$ adsorption equilibrium constant, and $\mathrm{P}_{\mathrm{CH}_{4}}$ and $\mathrm{P}_{\mathrm{H}_{2} \mathrm{O}}$ are the partial pressures of $\mathrm{CH}_{4}$ and $\mathrm{H}_{2} \mathrm{O}$, respectively. $\mathrm{K}_{\mathrm{H}_{2} \mathrm{O}}$ is exponentially dependent upon the $\mathrm{H}_{2} \mathrm{O}$ adsorption enthalpy $\left(\Delta H_{a d s}\right)$. To increase the activity and durability of the $\mathrm{Pd}$ catalysts in the presence of $\mathrm{H}_{2} \mathrm{O}, \mathrm{K}_{\mathrm{H}_{2} \mathrm{O}}$ should be small according to the above reaction model. Based on the measured $\Delta H_{a d s}$ values for water on supported Pd catalysts, water adsorbed on $\mathrm{Pd} / \mathrm{Al}_{2} \mathrm{O}_{3}$ has the highest negative adsorption enthalpy $\left(\Delta H_{\text {ads }}=-49 \mathrm{~kJ} \mathrm{~mol}^{-1}\right)$ compared to $\mathrm{Pd} / \mathrm{SnO}_{2}\left(-31 \mathrm{~kJ} \mathrm{~mol}^{-1}\right)$ and $\mathrm{Pd} / \mathrm{Al}_{2} \mathrm{O}_{3}-36 \mathrm{NiO}\left(-30 \mathrm{~kJ} \mathrm{~mol}^{-1}\right)$ (Table 7) despite the lower activation energy calculated for $\mathrm{Pd} / \mathrm{Al}_{2} \mathrm{O}_{3}$ (see Table 7) [16]. A higher $\left|\Delta H_{\text {ads }}\right|$ implies stronger $\mathrm{H}_{2} \mathrm{O}$ adsorption on the surface and is evidence of a higher coverage of active sites by $\mathrm{H}_{2} \mathrm{O}$ molecules on $\mathrm{Pd} / \mathrm{Al}_{2} \mathrm{O}_{3}$ catalysts and consequently lower catalyst activity. However, the larger negative enthalpy also predicts a more rapid decrease in $\mathrm{K}_{\mathrm{H} 2 \mathrm{O}}$ with increasing temperature for $\mathrm{Pd} / \mathrm{Al}_{2} \mathrm{O}_{3}$.

Table 7. Estimated kinetic parameters for $\mathrm{CH}_{4}$ oxidation using the rate equation $r=k_{r} \frac{\mathrm{P}_{\mathrm{CH}_{4}}}{1+\mathrm{K}_{\mathrm{H}_{2} \mathrm{O}} \mathrm{P}_{\mathrm{H}_{2} \mathrm{O}}}[16]$.

\begin{tabular}{cccc}
\hline Catalyst & $\begin{array}{c}\text { Pd loading } \\
(\mathbf{w t .} \%)\end{array}$ & $\begin{array}{c}\boldsymbol{E}_{\mathbf{a}} \\
\mathbf{k J} / \mathbf{m o l}\end{array}$ & $\Delta \boldsymbol{H}_{\text {ads }}$ for $\mathrm{H}_{2} \mathbf{O}$ \\
& 1.1 & 81 & $\mathbf{k J} / \mathbf{m o l}$ \\
$\mathrm{Pd} / \mathrm{Al}_{2} \mathrm{O}_{3}$ & 1.1 & 111 & -49 \\
$\mathrm{Pd} / \mathrm{SnO}_{2}$ & 1.1 & 90 & -31 \\
$\mathrm{Pd} / \mathrm{Al}_{2} \mathrm{O}_{3}-36 \mathrm{NiO}$ & & & -30 \\
\hline
\end{tabular}

The larger negative value in the order of $\mathrm{H}_{2} \mathrm{O}$ for the $1 \% \mathrm{Pd} / \mathrm{ZrO}_{2}$ catalyst, compared to the $\mathrm{Pd} / \mathrm{SiO}_{2}$ catalyst, as reported by Araya et al. [53] (Table 6), reflects stronger $\mathrm{H}_{2} \mathrm{O}$ adsorption on $\mathrm{ZrO}_{2}$ than on the $\mathrm{SiO}_{2}$ [53]. Hurtado et al. [83] observed a change in the power-law reaction order of $\mathrm{H}_{2} \mathrm{O}$ from -1.3 to -0.9 as temperature increased from $300{ }^{\circ} \mathrm{C}$ to $350{ }^{\circ} \mathrm{C}$ using a $\mathrm{H}_{2} \mathrm{O}-\mathrm{CH}_{4}-\mathrm{O}_{2}$ reactant mixture and a commercial $0.5 \mathrm{wt} . \% \mathrm{Pd} / \gamma-\mathrm{Al}_{2} \mathrm{O}_{3}$ catalyst. Considering the equation proposed by Kikuchi et al. [16], 
with $\mathrm{K}_{\mathrm{H}_{2} \mathrm{O}} \mathrm{P}_{\mathrm{H}_{2} \mathrm{O}} \gg 1$, the $\mathrm{H}_{2} \mathrm{O}$ reaction order will reduce to -1 but if $\mathrm{K}_{\mathrm{H}_{2} \mathrm{O}} \mathrm{P}_{\mathrm{H}_{2} \mathrm{O}}$ is small, the $\mathrm{H}_{2} \mathrm{O}$ reaction order reduces to a value approaching zero.

Hurtado et al. [83] also attributed the inhibition effect of $\mathrm{H}_{2} \mathrm{O}$ during reaction to the adsorption of $\mathrm{H}_{2} \mathrm{O}$ on $\mathrm{Pd}$ catalysts. Based on this assumption the authors examined several Eley-Rideal, Langmuir-Hinshelwood and Mars-van Krevelen kinetic models finding that by considering competitive adsorption between $\mathrm{H}_{2} \mathrm{O}$ and $\mathrm{CH}_{4}$ on $\mathrm{Pd}$ oxide sites and slow desorption of products, the following kinetic model could be derived:

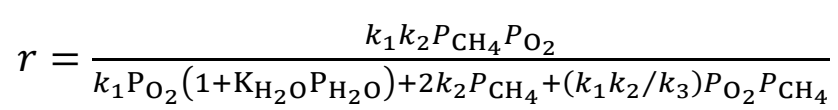

where $k_{1}, k_{2}$, and $\mathrm{k}_{3}$ are the rate constants for (1) irreversible oxygen adsorption, (2) surface reaction with $\mathrm{CH}_{4}$, and (3) product desorption steps in the mechanistic sequence, respectively. This model provides the best fit of their measured rate data. The $\Delta H_{\text {ads }}$ for water estimated from equation (7) is $-54.5 \mathrm{~kJ} / \mathrm{mol}$, in agreement with the data of Table 7. The inhibiting effects of $\mathrm{H}_{2} \mathrm{O}$ are assumed to be a consequence of a competitive adsorption between $\mathrm{CH}_{4}$ and $\mathrm{H}_{2} \mathrm{O}$ on $\mathrm{PdO}$ sites. Deactivation by $\mathrm{H}_{2} \mathrm{O}$ was previously thought to be due to formation of inactive $\mathrm{Pd}(\mathrm{OH})_{2}$ that does not participate in the $\mathrm{CH}_{4}$ oxidation reaction and is reversible at temperatures above $250{ }^{\circ} \mathrm{C}$ [66]. Hurtado et al. [83] also note that the formation of $\mathrm{Pd}(\mathrm{OH})_{2}$ is thermodynamically favored from $\mathrm{PdO}$ sites rather than from $\mathrm{Pd}^{0}$. However, the more recent mechanism involving $\mathrm{H}_{2} \mathrm{O}$ inhibition of the $\mathrm{O}$ exchange between $\mathrm{Pd}$ sites and oxide supports, proposed by Schwartz et al. [44,57] (see earlier discussion) appears to be supported by more definitive data.

\section{Conclusions}

Studies of the past decade provide new insights into the effects of $\mathrm{H}_{2} \mathrm{O}$ on $\mathrm{Pd}$ catalysts during $\mathrm{CH}_{4}$ oxidation, especially at lower temperatures. The principal effects of $\mathrm{H}_{2} \mathrm{O}$ are:

(a) reaction inhibition by $\mathrm{H}_{2} \mathrm{O}$ adsorption

(b) deactivation due to formation of $\mathrm{Pd}(\mathrm{OH})_{2}$ and

(c) $\mathrm{H}_{2} \mathrm{O}$-assisted sintering at high reaction temperatures $\left(>500{ }^{\circ} \mathrm{C}\right)$

Reaction inhibition by $\mathrm{H}_{2} \mathrm{O}$ increases with (a) decreasing reaction temperature at $<500{ }^{\circ} \mathrm{C}$ and (b) higher $\mathrm{H}_{2} \mathrm{O}$ concentrations, while this effect is generally negligible at $>500{ }^{\circ} \mathrm{C}$. O surface mobility of supports apparently influences $\mathrm{H}_{2} \mathrm{O}$ inhibition, i.e., high $\mathrm{O}$ mobility (on $\mathrm{CeO}_{2}$ and $\mathrm{ZrO}_{2}$ ) results in less inhibition by $\mathrm{H}_{2} \mathrm{O}$ than for $\mathrm{Al}_{2} \mathrm{O}_{3}$.

The main cause of partially reversible deactivation has been related to hydroxyl adsorption on the support and $\mathrm{PdO}$. Although earlier studies suggested that formation of inactive $\mathrm{Pd}(\mathrm{OH})_{2}$ could be the cause of deactivation, recent studies provide definitive evidence that adsorbed hydroxyls suppress $\mathrm{O}$ exchange between the support and $\mathrm{Pd}$ active sites causing suppression of catalyst activity.

$\mathrm{H}_{2} \mathrm{O}$-assisted sintering of supported $\mathrm{Pd}$ catalysts is observed at $>500{ }^{\circ} \mathrm{C}$. Catalysts with stabilized supports or core-shell structures have higher resistance to hydrothermal sintering. Several studies show that Pd bimetallic catalysts also improve catalyst stability, although explanations for the role of the second metal are not well-defined. Suppression of PdO sintering, enhanced oxygen mobility and suppression of hydroxide formation are postulated to play a key role in higher stability of Pd bimetallic catalysts. 
Rate expressions from kinetic studies of $\mathrm{CH}_{4}$ oxidation at conditions relevant to natural gas vehicles are based on the assumptions of (a) product inhibition by $\mathrm{H}_{2} \mathrm{O}$ is a consequence of a competitive adsorption mechanism between $\mathrm{CH}_{4}$ and $\mathrm{H}_{2} \mathrm{O}$ on $\mathrm{PdO}$ sites; and (b) deactivation by $\mathrm{H}_{2} \mathrm{O}$ is due to the formation of inactive $\mathrm{Pd}(\mathrm{OH})_{2}$. None of the previous kinetic studies have linked the observed kinetic effects of $\mathrm{H}_{2} \mathrm{O}$ to $\mathrm{O}$ mobility that recent studies show is critical during $\mathrm{CH}_{4}$ oxidation.

\section{Acknowledgements}

The financial support of Westport Innovations Inc. and Natural Sciences and Engineering Research Council of Canada (NSERC) is gratefully acknowledged.

\section{References}

1. US Government. The World Factbook 2013-14. Washington, DC: Central Intelligence Agency, 2013. Available online: https://www.cia.gov/library/publications/the-world-factbook/geos/xx.html (accessed on 1 September 2013).

2. Natural Gas Vehicle Knowledge Base, Statistics. Available online: http:/www.iangv.org/category/stats/ 2014 (Accessed on 25 March 2015).

3. Bartholomew, C.H.; Farrauto, R.J. Fundamentals of Industrial Catalytic Processes, 2nd ed.; J. Wiley and Sons Inc: Hoboken, NJ, USA, 2006.

4. Barbier, J., Jr.; Duprez, D. Steam Effects in Three-Way Catalysis. Appl. Catal. B 1994, 4, 105-140.

5. Lox, E.S.J.; Engler, B.H. In Handbook of Heterogeneous Catalysis; Ertl, G., Knozinger, H., Weitkamp, J., Eds.; Wiley-VCH: Weinheim, Germany, 1997; Volume 4.

6. Ciuparu, D.; Lyubovsky, M.R.; Altman, E.; Pfefferle, L.D.; Datye, A. Catalytic Combustion of Methane over Palladium-Based Catalysts. Catal. Rev. Sci. Eng. 2002, 44, doi:10.1081/CR-120015482.

7. Silver, R.G.; Summers, J.C. In Catalysis and Automotive Pollution Control III Studies in Surface Science and Catalysis; Frennet, A., Bastin, J.M., Eds.; Elsevier Science: Amsterdam, The Netherlands, 1995; pp. 871-884.

8. Klingstedt, F.; Neyestanaki, A.K.; Byggningsbacka, R.; Lindfors, L.; Lundén, M.; Petersson, M.; Tengström, P.; Ollonqvist, T.; Väyrynen, J. Palladium Based Catalysts for Exhaust Aftertreatment of Natural Gas Powered Vehicles and Biofuel Combustion. Appl. Catal. A 2001, 209, 301-316.

9. Farrauto, R.J.; Hobson, M.C.; Kennelly, T.; Waterman, E.M. Catalytic Chemistry of Supported Palladium for Combustion of Methane. Appl. Catal. A 1992, 81, 227-237.

10. Lampert, J.K.; Kazi, M.S.; Farrauto, R.J. Palladium Catalyst Performance for Methane Emissions Abatement from Lean Burn Natural Gas Vehicles. Appl. Catal. B 1997, 14, 211-223.

11. Bounechada, D.; Groppi, G.; Forzatti, P.; Kallinen, K.; Kinnunen, T. Effect of Periodic lean/rich Switch on Methane Conversion over a Ce-Zr Promoted $\mathrm{Pd}-\mathrm{Rh} / \mathrm{Al}_{2} \mathrm{O}_{3}$ catalyst in the Exhausts of Natural Gas Vehicles. Appl. Catal. B 2012, 119-120, 91-99.

12. Gelin, P.; Primet, M. Complete Oxidation of Methane at Low Temperature over Noble Metal Based Catalysts: A Review. Appl. Catal. B 2002, 39, 1-37. 
13. Choudhary, T.V.; Banerjee, S.; Choudhary, V.R. Catalysts for Combustion of Methane and Lower Alkanes. Appl. Catal. A 2002, 234, 1-23.

14. Centi, G. Supported Palladium Catalysts in Environmental Catalytic Technologies for Gaseous Emissions. J. Mol. Catal. A 2001, 173, 287-312.

15. Forzatti, P.; Groppi, G. Catalytic Combustion for the Production of Energy. Catal. Today 1999, 54, $165-180$.

16. Kikuchi, R.; Maeda, S.; Sasaki, K.; Wennerström, S.; Eguchi, K. Low-Temperature Methane Oxidation over Oxide-Supported Pd Catalysts: Inhibitory Effect of Water Vapor. Appl. Catal. A 2002, 232, 23-28.

17. Pieck, C.L.; Vera, C.R.; Peirotti, E.M.; Yori, J.C. Effect of Water Vapor on the Activity of Pt-Pd/Al $\mathrm{Al}_{2} \mathrm{O}_{3}$ Catalysts for Methane Combustion. Appl. Catal. A 2002, 226, 281-291.

18. Roth, D.; Gélin, P.; Primet, M.; Tena, E. Catalytic Behaviour of Cl-Free and Cl-Containing $\mathrm{Pd} / \mathrm{Al}_{2} \mathrm{O}_{3}$ Catalysts in the Total Oxidation of Methane at Low Temperature. Appl. Catal. A 2000, 203, 37-45.

19. Lapisardi, G.; Urfels, L.; Gélin, P.; Primet, M.; Kaddouri, A.; Garbowski, E.; Toppi, S.; Tena, E. Superior Catalytic Behaviour of Pt-Doped Pd Catalysts in the Complete Oxidation of Methane at Low Temperature. Catal. Today 2006, 117, 564-568.

20. Li, Z.; Hoflund, G.B. A Review on Complete Oxidation of Methane at Low Tempertaure. J. Nat. Gas Chem. 2003, 12, 153-160.

21. Colussi, S.; Gayen, A.; Camellone, M.F.; Boaro, M.; Llorca, J.; Fabris, S.; Trovarelli, A. Nanofaceted Pd-O Sites in Pd-Ce Surface Superstructures: Enhanced Activity in Catalytic Combustion of Methane. Angew. Chem. Int. Ed. 2009, 48, 8633-8636.

22. Cargnello, M.; Jaén, J.J.D.; Garrido, J.C.H.; Bakhmutsky, K.; Montini, T.; Gámez, J.J.C.; Gorte, R.J.; Fornasiero, P. Exceptional Activity for Methane Combustion over Modular $\mathrm{Pd} @ \mathrm{CeO}_{2}$ Subunits on Functionalized $\mathrm{Al}_{2} \mathrm{O}_{3}$. Science 2012, 337, 713-717.

23. Hellman, A.; Resta, A.; Martin, N.M.; Gustafson, J.; Trinchero, A.; Carlsson, P.-A.; Balmes, O.; Felici, R.; van Rijn, R.; Frenken, J.W.M.; Andersen, J.N.; Lundgren, E.; Gronbeck, H. The Active Phase of Palladium during Methane Oxidation. J. Phys. Chem. Lett. 2012, 3, 678-682.

24. Briot, P.; Primet, M. Catalytic Oxidation of Methane over Palladium Supported on Alumina: Effect of Aging Under Reactants. Appl. Catal. 1991, 68, 301-314.

25. Gélin, P.; Urfels, L.; Primet, M.; Tena, E. Complete Oxidation of Methane at Low Temperature over Pt and Pd Catalysts for the Abatement of Lean-Burn Natural Gas Fuelled Vehicles Emissions: Influence of Water and Sulphur Containing Compounds. Catal. Today 2003, 83, 45-57.

26. Bartholomew, C.H. Mechanisms of Catalyst Deactivation. Appl. Catal. A 2001, 212, 17-60.

27. Kang, S.; Han, S.; Nam, S.; Nam, I.; Cho, B.; Kim, C.; Oh, S. Effect of Aging Atmosphere on Thermal Sintering of Modern Commercial TWCs. Top. Catal. 2013, 56, 298-305.

28. Shinjoh, H. Noble Metal Sintering Suppression Technology in Three-Way Catalyst: Automotive Three-Way Catalysts with the Noble Metal Sintering Suppression Technology Based on the Support Anchoring Effect. Catal. Surv. Asia 2009, 13, 184-190.

29. Fathali, A.; Olsson, L.; Ekstrom, F.; Laurell, M.; Andersson, B. Hydrothermal Aging-Induced Changes in Washcoats of Commercial Three-Way Catalysts. Top. Catal. 2013, 56, 323-328. 
30. Ciuparu, D.; Perkins, E.; Pfefferle, L. In Situ DR-FTIR Investigation of Surface Hydroxyls on $\gamma-\mathrm{Al}_{2} \mathrm{O}_{3}$ Supported PdO Catalysts during Methane Combustion. Appl. Catal. A 2004, 263, 145-153.

31. Burch, R.; Urbano, F.J.; Loader, P.K. Methane Combustion Over Palladium Catalysts: The Effect of Carbon Dioxide and Water on Activity. Appl. Catal. A 1995, 123, 173-184.

32. Gao, D.; Wang, S.; Zhang, C.; Yuan, Z.; Wang, S. Methane Combustion over $\mathrm{Pd} / \mathrm{Al}_{2} \mathrm{O}_{3}$ Catalyst: Effects of Chlorine Ions and Water on Catalytic Activity. Chin. J. Catal. 2008, 29, 1221-1225.

33. Park, J.; Kim, B.; Shin, C.; Seo, G.; Kim, S.; Hong, S. Methane Combustion over Pd Catalysts Loaded on Medium and Large Pore Zeolites. Top. Catal. 2009, 52, 27-34.

34. Stasinska, B.; Machocki, A.; Antoniak, K.; Rotko, M.; Figueiredo, J.L.; Gonçalves, F. Importance of Palladium Dispersion in $\mathrm{Pd} / \mathrm{Al}_{2} \mathrm{O}_{3}$ Catalysts for Complete Oxidation of Humid Low-methane-air Mixtures. Catal. Today 2008, 137, 329-334.

35. Persson, K.; Pfefferle, L.D.; Schwartz, W.; Ersson, A.; Järås, S.G. Stability of Palladium-Based Catalysts during Catalytic Combustion of Methane: The Influence of Water. Appl. Catal. B 2007, 74, 242-250.

36. Liu, Y.; Wang, S.; Gao, D.; Sun, T.; Zhang, C.; Wang, S. Influence of Metal Oxides on the Performance of $\mathrm{Pd} / \mathrm{Al}_{2} \mathrm{O}_{3}$ Catalysts for Methane Combustion Under Lean-Fuel Conditions. Fuel Process. Technol. 2013, 111, 55-61.

37. Zhu, G.; Han, J.; Zemlyanov, D.Y.; Ribeiro, F.H. Temperature Dependence of the Kinetics for the Complete Oxidation of Methane on Palladium and Palladium Oxide. J. Phys. Chem. B 2005, 109, 2331-2337.

38. Okumura, K.; Shinohara, E.; Niwa, M. Pd Loaded on High Silica Beta Support Active for the Total Oxidation of Diluted Methane in the Presence of Water Vapor. Catal. Today 2006, 117, 577-583.

39. Nomura, K.; Noro, K.; Nakamura, Y.; Yoshida, H.; Satsuma, A.; Hattori, T. Combustion of a Trace Amount of $\mathrm{CH}_{4}$ in the Presence of Water Vapor over $\mathrm{ZrO}_{2}$-Supported Pd Catalysts. Catal. Lett. 1999, 58, 127-130.

40. Cullis, C.F.; Nevell, T.G.; Trimm, D.L. Role of the Catalyst Support in the Oxidation of Methane over Palladium. Faraday Trans. 1972, 68, 1406-1412.

41. Eriksson, S.; Boutonnet, M.; Järås, S. Catalytic Combustion of Methane in Steam and Carbon Dioxide-Diluted Reaction Mixtures. Appl. Catal. A 2006, 312, 95-101.

42. Ciuparu, D.; Katsikis, N.; Pfefferle, L. Temperature and Time Dependence of the Water Inhibition Effect on Supported Palladium Catalyst for Methane Combustion. Appl. Catal. A 2001, 216, 209-215.

43. Ciuparu, D.; Pfefferle, L. Support and Water Effects on Palladium Based Methane Combustion Catalysts. Appl. Catal. A 2001, 209, 415-428.

44. Schwartz, W.R.; Ciuparu, D.; Pfefferle, L.D. Combustion of Methane over Palladium-Based Catalysts: Catalytic Deactivation and Role of the Support. J. Phys. Chem. C 2012, 116, 8587-8593.

45. Hansen, T.W.; DeLaRiva, A.T.; Challa, S.R.; Datye, A.K. Sintering of Catalytic Nanoparticles: Particle Migration Or Ostwald Ripening? Acc. Chem. Res. 2013, 46, 1720-1730. 
46. Lamber, R.; Jaeger, N.; Schulz-Ekloff, G. Metal-Support Interaction in the $\mathrm{Pd} / \mathrm{SiO}_{2} \mathrm{System:}$ Influence of the Support Pretreatment. J. Catal. 1990, 123, 285-297.

47. Nagai, Y.; Hirabayashi, T.; Dohmae, K.; Takagi, N.; Minami, T.; Shinjoh, H.; Matsumoto, S. Sintering Inhibition Mechanism of Platinum Supported on Ceria-Based Oxide and Pt-oxidesupport Interaction. J. Catal. 2006, 242, 103-109.

48. Xu, Q.; Kharas, K.C.; Croley, B.J.; Datye, A.K. The Sintering of Supported Pd Automotive Catalysts. ChemCatChem 2011, 3, 1004-1014.

49. Escandón, L.S.; Niño, D.; Díaz, E.; Ordóñez, S.; Díez, F.V. Effect of Hydrothermal Ageing on the Performance of Ce-Promoted $\mathrm{PdO} / \mathrm{ZrO}_{2}$ for Methane Combustion. Catal. Commun. 2008, 9 , 2291-2296.

50. Muto, K.; Katada, N.; Niwa, M. Complete Oxidation of Methane on Supported Palladium Catalyst: Support Effect. Appl. Catal. A 1996, 134, 203-215.

51. Narui, K.; Yata, H.; Furuta, K.; Nishida, A.; Kohtoku, Y.; Matsuzaki, T. Effects of Addition of Pt to $\mathrm{PdO} / \mathrm{Al}_{2} \mathrm{O}_{3}$ Catalyst on Catalytic Activity for Methane Combustion and TEM Observations of Supported Particles. Appl. Catal. A 1999, 179, 165-173.

52. Zhang, B.; Wang, X.; M'Ramadj, O.; Li, D.; Zhang, H.; Lu, G. Effect of Water on the Performance of Pd-ZSM-5 Catalysts for the Combustion of Methane. J. Nat. Gas Chem. 2008, 17, 87-92.

53. Araya, P.; Guerrero, S.; Robertson, J.; Gracia, F.J. Methane Combustion over $\mathrm{Pd} / \mathrm{SiO}_{2} \mathrm{Catalysts}$ with Different Degrees of Hydrophobicity. Appl. Catal. A 2005, 283, 225-233.

54. Lu, J.; Fu, B.; Kung, M.C.; Xiao, G.; Elam, J.W.; Kung, H.H.; Stair, P.C. Coking- and Sintering-Resistant Palladium Catalysts Achieved through Atomic Layer Deposition. Science 2012, 335, 1205-1208.

55. Forman, A.J.; Park, J.; Tang, W.; Hu, Y.; Stucky, G.D.; McFarland, E.W. Silica-Encapsulated Pd Nanoparticles as a Regenerable and Sintering-Resistant Catalyst. ChemCatChem 2010, 2, 1318-1324.

56. Adijanto, L.; Bennett, D.A.; Chen, C.; Yu, A.S.; Cargnello, M.; Fornasiero, P.; Gorte, R.J.; Vohs, J.M. Exceptional Thermal Stability of $\mathrm{Pd} @ \mathrm{CeO}_{2}$ Core-Shell Catalyst Nanostructures Grafted Onto an Oxide Surface. Nano Lett. 2013, 13, 2252-2257.

57. Schwartz, W.R.; Pfefferle, L.D. Combustion of Methane over Palladium-Based Catalysts: Support Interactions. J. Phys. Chem. C 2012, 116, 8571-8578.

58. Gannouni, A.; Albela, B.; Zina, M.S.; Bonneviot, L. Metal Dispersion, Accessibility and Catalytic Activity in Methane Oxidation of Mesoporous Templated Aluminosilica Supported Palladium. Appl. Catal. A 2013, 464-465, 116-127.

59. Zhu, G.; Fujimoto, K.; Zemlyanov, D.Y.; Datye, A.K.; Ribeiro, F.H. Coverage of Palladium by Silicon Oxide during Reduction in $\mathrm{H}_{2}$ and Complete Oxidation of Methane. J. Catal. 2004, 225, 170-178.

60. Jacobson, N.S.; Opila, E.J.; Myers, D.L.; Copland, E.H. Thermodynamics of Gas Phase Species in the Si-O-H System. J. Chem. Thermodyn. 2005, 37, 1130-1137.

61. Opila, E.; Jacobson, N.; Myers, D.; Copland, E. Predicting Oxide Stability in High-Temperature Water Vapor. JOM 2006, 58, 22-28. 
62. Lund, C.R.F.; Dumesic, J.A. Strong Oxide-Oxide Interactions in Silica-Supported Fe3O4: III. Water-Induced Migration of Silica on Geometrically Designed Catalysts. J. Catal. 1981, 72, 21-30.

63. Yoshida, H.; Nakajima, T.; Yazawa, Y.; Hattori, T. Support Effect on Methane Combustion over Palladium Catalysts. Appl. Catal. B 2007, 71, 70-79.

64. Persson, K.; Ersson, A.; Colussi, S.; Trovarelli, A.; Järås, S.G. Catalytic Combustion of Methane over Bimetallic Pd-Pt Catalysts: The Influence of Support Materials. Appl. Catal. B 2006, 66, 175-185.

65. Guerrero, S.; Araya, P.; Wolf, E.E. Methane Oxidation on Pd Supported on High Area Zirconia Catalysts. Appl. Catal. A 2006, 298, 243-253.

66. Card, R.J.; Schmitt, J.L.; Simpson, J.M. Palladium-Carbon Hydrogenolysis Catalysts: The Effect of Preparation Variables on Catalytic Activity. J. Catal. 1983, 79, 13-20.

67. Kan, H.H.; Colmyer, R.J.; Asthagiri, A.; Weaver, J.F. Adsorption of Water on a PdO(101) Thin Film: Evidence of an Adsorbed $\mathrm{HO}-\mathrm{H}_{2} \mathrm{O}$ Complex. J. Phys. Chem. C 2009, 113, 1495-1506.

68. Fujimoto, K.; Ribeiro, F.H.; Avalos-Borja, M.; Iglesia, E. Structure and Reactivity of PdOx/ZrO 2 Catalysts for Methane Oxidation at Low Temperatures. J. Catal. 1998, 179, 431-442.

69. Chin, Y.; Iglesia, E. Elementary Steps the Role of Chemisorbed Oxygen, and the Effects of Cluster Size in Catalytic $\mathrm{CH}_{4}-\mathrm{O}_{2}$ Reactions on Palladium. J. Phys. Chem. C 2011, 115, 17845-17855.

70. Ciuparu, D.; Pfefferle, L. Contributions of Lattice Oxygen to the overall Oxygen Balance during Methane Combustion over PdO-Based Catalysts. Catal. Today 2002, 77, 167-179.

71. Abbasi, R.; Wu, L.; Wanke, S.E.; Hayes, R.E. Kinetics of Methane Combustion over Pt and Pt-Pd Catalysts. Chem. Eng. Res. Des. 2012, 90, 1930-1942.

72. Yamamoto, H.; Uchida, H. Oxidation of Methane over Pt and Pd Supported on Alumina in Lean-Burn Natural-Gas Engine Exhaust. Catal. Today 1998, 45, 147-151.

73. Persson, K.; Ersson, A.; Jansson, K.; Iverlund, N.; Järås, S. Influence of Co-Metals on Bimetallic Palladium Catalysts for Methane Combustion. J. Catal. 2005, 231, 139-150.

74. Persson, K.; Ersson, A.; Jansson, K.; Fierro, J.L.G.; Järås, S.G. Influence of Molar Ratio on Pd-Pt Catalysts for Methane Combustion. J. Catal. 2006, 243, 14-24.

75. Persson, K.; Jansson, K.; Järås, S.G. Characterisation and Microstructure of Pd and Bimetallic Pd-Pt Catalysts during Methane Oxidation. J. Catal. 2007, 245, 401-414.

76. Kuper, W.J.; Blaauw, M.; Berg, F.V.; Graaf, G.H. Catalytic Combustion Concept for Gas Turbines. Catal. Today 1999, 47, 377-389.

77. Ozawa, Y.; Tochihara, Y.; Watanabe, A.; Nagai, M.; Omi, S. Deactivation of $\mathrm{Pt} \cdot \mathrm{PdO} / \mathrm{Al}_{2} \mathrm{O}_{3}$ in Catalytic Combustion of Methane. Appl. Catal. A 2004, 259, 1-7.

78. Ishihara, T. Effects of Additives on the Activity of Palladium Catalysts for Methane Combustion. Chem. Lett. 1993, 22, 407-410.

79. Carstens, J.N.; Su, S.C.; Bell, A.T. Factors Affecting the Catalytic Activity of $\mathrm{Pd} / \mathrm{ZrO}_{2}$ for the Combustion of Methane. J. Catal. 1998, 176, 136.

80. Zhu, G.; Han, J.; Zemlyanov, D.Y.; Ribeiro, F.H. The Turnover Rate for the Catalytic Combustion of Methane over Palladium is Not Sensitive to the Structure of the Catalyst. J. Am. Chem. Soc. 2004, 126, 9896-9897. 
81. Monteiro, R.S.; Zemlyanov, D.; Storey, J.M.; Ribeiro, F.H. Turnover Rate and Reaction Orders for the Complete Oxidation of Methane on a Palladium Foil in Excess Dioxygen. J. Catal. 2001, 199, 291-301.

82. Ribeiro, F.H.; Chow, M.; Dallabetta, R.A. Kinetics of the Complete Oxidation of Methane over Supported Palladium Catalysts. J. Catal. 1994, 146, 537-544.

83. Hurtado, P.; Ordóñez, S.; Sastre, H.; Díez, F.V. Development of a Kinetic Model for the Oxidation of Methane over $\mathrm{Pd} / \mathrm{Al}_{2} \mathrm{O}_{3}$ at Dry and Wet Conditions. Appl. Catal. B 2004, 51, 229-238.

(C) 2015 by the authors; licensee MDPI, Basel, Switzerland. This article is an open access article distributed under the terms and conditions of the Creative Commons Attribution license (http://creativecommons.org/licenses/by/4.0/). 